\title{
GENISTEIN REDUCES PRODUCTION OF \\ PROINFLAMMATORY MOLECULES IN HUMAN \\ CHONDROCYTES
}

\author{
By \\ SHIRIN HOOSHMAND \\ Bachelor of Science in Nutritional Sciences \\ Shah d Beheshti University of Medical Sciences \\ Tehran, Iran \\ 2004
}
Submitted to the Faculty of the
Graduate College of the
Oklahoma State University in partial fulfillment of the requirements for the Degree of MASTER OF SCIENCE

May, 2006 
GENISTEIN REDUCES PRODUCTION OF

PROINFLAMMATORY MOLECULES IN HUMAN

CHONDROCYTES

Thesis Approved:

Dr. Bahram H. Arjmandi

Thesis Adviser

Dr. Edralin A. Lucas

Dr. Sundar V. Madihally

Dr. A. Gordon Emslie

Dean of the Graduate College 


\section{ACKNOWLEDGMENTS}

I wish to express my deepest gratitude and sincere appreciation to my major advisor, Dr. Bahram H. Arjmandi, for his encouragement and guidance throughout the course of my study. Working with him has been a tremendous learning process for me. I will never be able to thank him enough for his support.

I would also like to extend my appreciation to the members of my graduate committee, Dr. Edralin A. Lucas, for showing interest in this work and providing me with useful suggestions and Dr. Sundar V. Madihally, for sharing his knowledge and guidance. I will always be grateful to them.

In addition to my committee, I would like to acknowledge the time and efforts that Dr. Do Yu Soung contributed to this study. I would also like to thank Dr. Latha Devareddy, for her guidance and contribution to the success of my thesis in many ways. Without all of you, this goal would have not become a reality.

A final thank you is given to my family who has always loved and encouraged me. To my wonderful mother, for her endless love and confidence towards me; she has made my goals possible and my future bright, to my sisters, Shadi and Shiva, for their never-ending support and unconditional love. I have dedicated this to you! 


\section{TABLE OF CONTENTS}

\section{$\begin{array}{lll}\text { Chapter } & \text { Page }\end{array}$}

\section{INTRODUCTION}

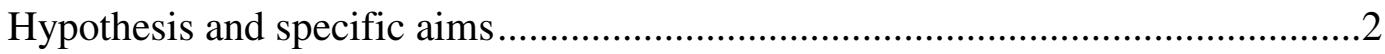

\section{REVIEW OF LITERATURE}

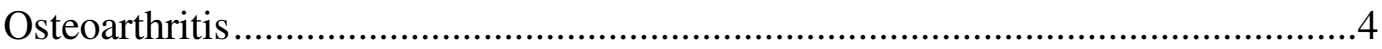

Epidemiology and prevalence...........................................................................

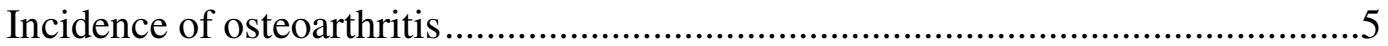

Primary and secondary osteoarthritis .................................................................

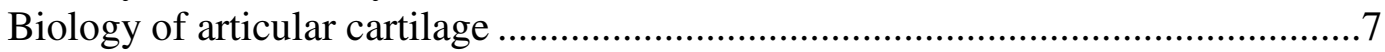

Composition of cartilage .............................................................................

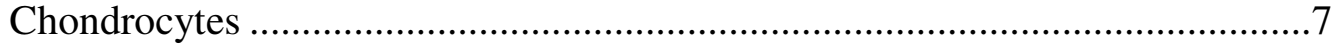

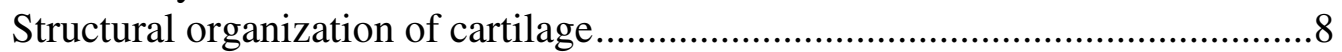

Pathogenesis, clinical features, and risk factors of osteoarthritis ...........................

Changes in the diseased joint .............................................................................10

Morphological changes .............................................................................

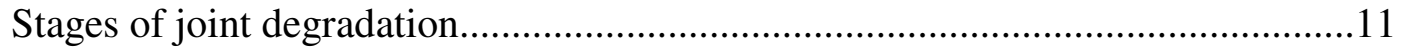

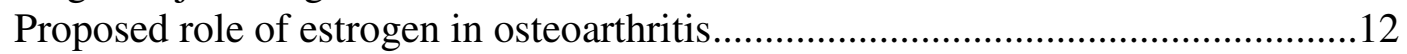

Estrogen receptors and selective estrogen receptor modulators ...............................14

Estrogen receptor .....................................................................................14

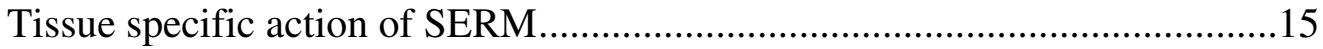

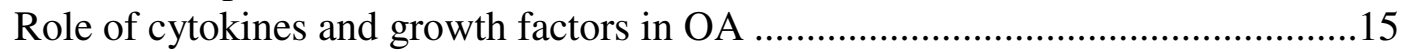

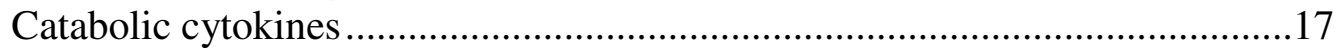

Markers of cartilage degradation .....................................................................18

Current treatment and therapies for OA-medications ............................................18

Class of non-steroidal anti-inflammatory agents ............................................18

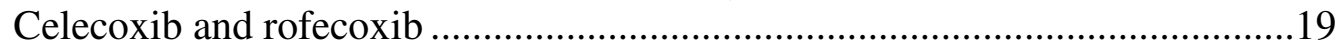

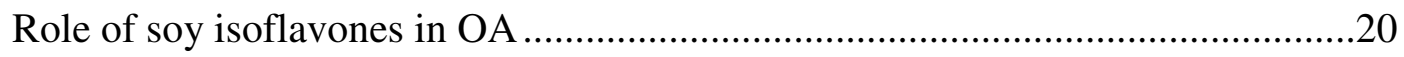

\section{RESEARCH DESIGN AND METHODS}

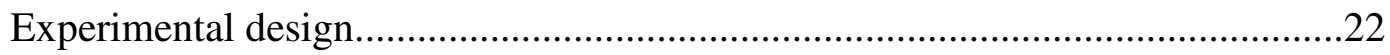

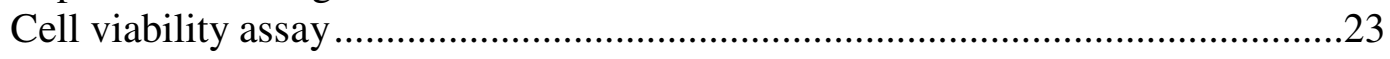

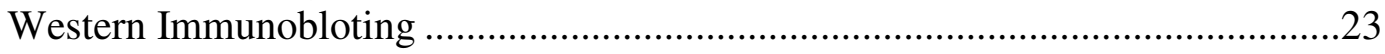




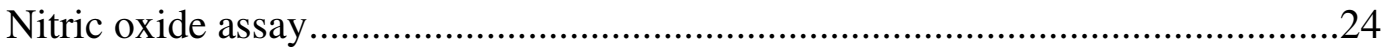

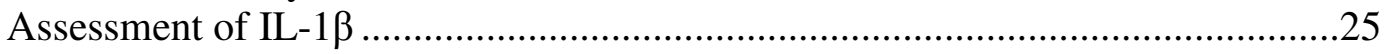

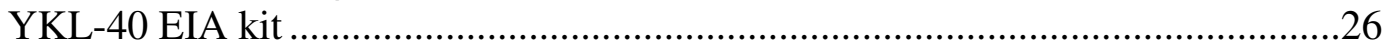

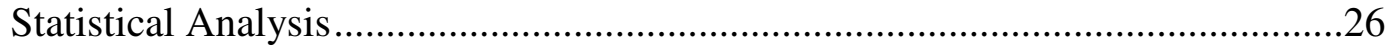

IV. RESULTS

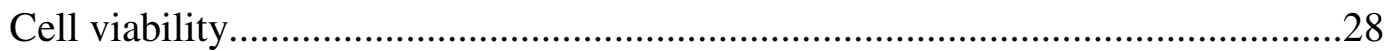

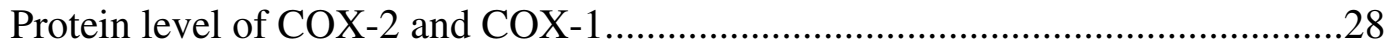

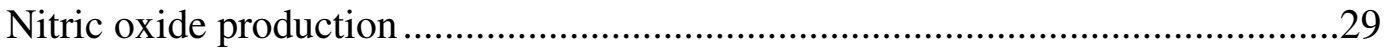

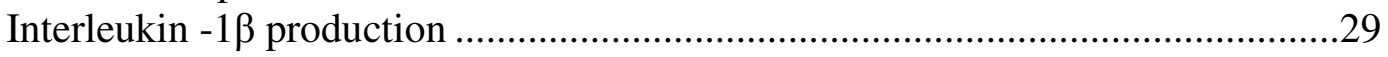

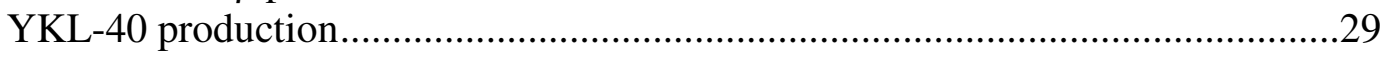

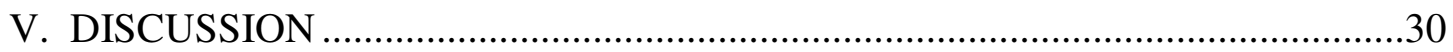

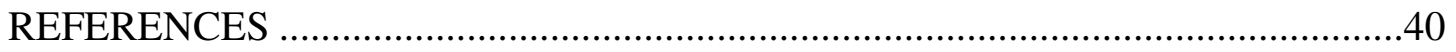




\section{LIST OF FIGURES}

$\begin{array}{lll}\text { Figure } & \text { Page }\end{array}$

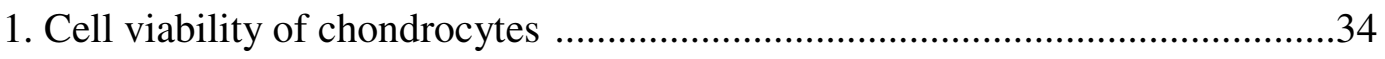

2. COX-2 protein level of cytosolic fraction of chondrocytes ................................35

3. COX-1 protein level of cytosolic fraction of chondrocytes ................................36

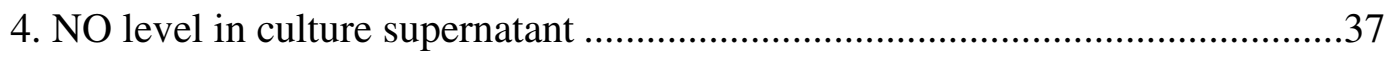

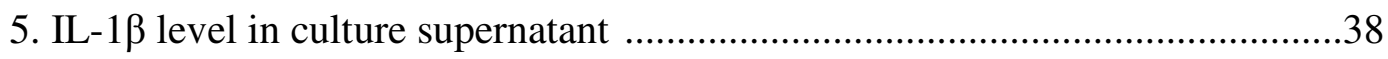

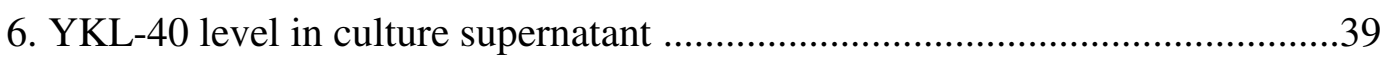




\section{NOMENCLATURE}

\begin{tabular}{|c|c|}
\hline $\mathrm{CON}$ & Control \\
\hline $\mathrm{COX}$ & Cyclooxygenase \\
\hline EIA & Enzyme immunoassay \\
\hline ELISA & Enzyme immunosorbent assay \\
\hline ER & Estrogen receptor \\
\hline ERT & Estrogen replacement therapy \\
\hline HRP & Horse radish peroxidase \\
\hline IL-1 $\beta$ & Interleukin-1 beta \\
\hline LOX & Lipoxygenase \\
\hline LPS & Lipopolysaccharide \\
\hline MMP & Metalloproteinase \\
\hline $\mathrm{NF}-\kappa \mathrm{B}$ & Nuclear factor kappa B \\
\hline NO & Nitric oxide \\
\hline NSAID & Nonestradiol antiinflammatory drug \\
\hline $\mathrm{OA}$ & Osteoarthritis \\
\hline PVDF & Polyvinylidene diflouride \\
\hline RA & Rheumatoid arthritis \\
\hline SERM & Selective estrogen receptor modulator \\
\hline SDS & Sodium dodecyl sulfate \\
\hline TNF- $\alpha$ & Tumor necrosis factor alpha \\
\hline
\end{tabular}




\section{CHAPTER I}

\section{INTRODUCTION}

Osteoarthritis (OA) is the most common joint disorder and its etiology is relatively unknown. After age 45, women experience a more dramatic increase in the incidence of OA compare to men. The gender difference in prevalence of OA has been linked to ovarian hormone deficiency. Intraarticular injections of estradiol has been shown to upregulate both estrogen receptors in condylar cartilage at early stages of OA in ovariectomized rabbits(1;2). A recent ex vivo study (3) indicated that postmenopausal women with knee OA had elevated estrogen levels in knee synovial fluid without notable differences in circulating estrogen levels.

Although the etiology of OA is not completely known, it is believed that production of proinflammatory cytokines in the joints may play a crucial role in the pathogenesis of OA. Management of OA's symptoms is currently focused on reducing pain and inflammation through nonestradiol antiinflammatory drugs (NSAIDs) or other agents. The findings of some recent studies $(4 ; 5)$ have suggested that plant flavonoids attenuate inflammation and the immune response through their inhibition of important regulatory enzymes in arachidonic acid metabolism. Flavonoids are powerful inhibitors of cyclooxygenase-2 (COX-2) activity $(5 ; 6)$. These antiinflammatory properties of flavonoids provide the rationale for investigating the role of isoflavones in conditions such as OA. A recent clinical study by Arjmandi and colleagues (7) indicated thatsoy 
protein supplementation delivering $88 \mathrm{mg}$ isoflavons mainly in the form of genistein, a naturally-occurring selective estrogen receptor modulator (SERM), was effective in alleviating overall OA symptoms and reducing pain medication use. The major isoflavone in soy is genistein, which has been referred to as naturally occurring selective estrogen receptor modulator with resemblance to synthetic SERMs such as tamoxifen, raloxifene, and ipriflavone. Tamoxifen (8), raloxifene (9) and ipriflavone (10) have been shown to have beneficial effect on cartilage metabolism and alleviate OA symptoms. The purpose of the presentstudy was to determine whether genistein inhibits the production of proinflammatory molecules in lipopolysaccharide (LPS)-stimulated chondrocytes.

\section{Hypothesis}

The hypothesis of this study was that genistein dose-dependently suppresses the production of LPS-induced proinflammatory molecules in human chondrocytes.

The specific aims of this research were as follows:

1. To investigate the extent to which genistein reduces LPS-induced production of proinflammatory molecule, i.e. COX-2, nitric oxide (NO), tumor necrosis factoralpha (TNF- $\alpha$ ), and interleukin-1 beta (IL-1 $\beta)$.

2. To explore whether the antiinflammatory properties of genistein in chondrocytes, in part, is through estrogen receptors. For this purpose ICI-182,780, an estrogen receptor (ER) antagonist, was used.

3. To compare the antiinflammatory properties of genistein against a known selective inhibitor of COX-2. 
4. To examine whether genistein restore formation of glycoprotein synthesis in LPS stilmulated chondrocytes by measuring, YKL-40, a marker of cartilage degradation. 


\section{CHAPTER II}

\section{REVIEW OF LITERATURE}

\section{Osteoarthritis}

\section{Epidemiology and Prevalence}

Osteoarthritis (OA) is the leading cause of disability in the elderly population. In the United States, it afflicts $13 \%$ of individuals between the ages of 55 and 64 and $17 \%$ of those 65 to 74 years old (11). Currently, 20 million people in the U.S. are affected by OA and this number is predicted to exceed 59 million by the year 2020 (12). Increasing prevalence of OA with age is further aggravated by the lack of treatment to reduce the overall cause of OA. It is the most common joint disorder, both in the U.S. and throughout the world, with relatively unknown etiology. Exhausting a major proportion of health care dollars, OA ranks second in health care problems of the developed world (13). The relative economic impact of musculoskeletal conditions is growing rapidly with the passage of time, having reached $2.5 \%$ of the gross national product in 1992 . The prevalence of OA is higher in men than in women up to approximately age 45, however, after age 45 the reverse is true (14). The epidemiologic definition of OA encompasses symptoms, disability, and structural changes associated with this disorder. Epidemiological data focus not only on the structural disease but also characterizes the radiographical definition with the presence and absence of symptoms. The most widely used system for grading the severity of the radiograph is known as the Kellgren- 
Lawrence grading system (14). This grading defines the degree of osteophyte formation from 0 to 4 but is unclear on the issue of grading the knee with joint space narrowing without the presence of osteophytes.

\section{Incidence of Osteoarthritis}

Reports on the percentage of people who have been diagnosed with osteoarthritis based on medical history, examination, or radiographic evaluation confirm a striking increase in the prevalence of OA of the hand, foot, knee, and hip joints with increasing age $(15 ; 16)$. In the Framingham study population, it was found that the percentage of people who have mild, moderate, or severe radiographic changes indicative of osteoarthritis in at least one joint increases progressively from less than 5\% in individuals younger than 25 years of age to more than $80 \%$ in individuals more than 75 years of age $(17 ; 18)$. More specifically, those with moderate or severe radiographic changes in relation to $\mathrm{OA}$ in at least one joint increases dramatically from $5 \%$ in individuals younger than 45 years of age to $40 \%$ in those 75 years and older (15). Regardless of the relationship between age and $\mathrm{OA}$, the widespread view is that osteoarthritis results from normal wear and tear.

Unlike the joint destruction seen in other rheumatic joint diseases with major systemic inflammatory components such as rheumatoid arthritis (RA), OA consists of a regressive sequence of changes in the cells and matrix that results in the loss of structure and function of articular cartilage accompanied by attempts at cartilage repair and the remodeling of underlying bones $(19 ; 20)$. Because of these repair and remodeling processes, the degeneration of the articular surface in OA is not uniformly progressive, and the rate of degeneration varies among individuals and among joints $(21 ; 22)$. On 
occasions, this degeneration may occur rapidly, but in most joints it progresses slowly over many years. However, in some cases, this process may stabilize or even decrease spontaneously with partial restoration of the articular surface and a resulting decrease in symptoms.

\section{$\underline{\text { Primary and Secondary Osteoarthritis }}$}

Primary or idiopathic osteoarthritis is the degeneration of articular cartilage and alterations in single or multiple joints due primarily to aging and wear and tear of the tissue. This results in the loss of structure and function of the articular cartilage causing pain and loss of motion (23). In an increasing number of individuals, OA is classified as secondary on the basis that the joint degeneration is mainly as a result of traumatic joint injury or from developmental, metabolic, and systemic disorders which destroy the articular surface (23). This generally progressive loss of articular cartilage is accompanied by attempted repair of the cartilage, remodeling and sclerosis of the underlying subchondral bone, and in many cases the formation of bone cysts and marginal osteophytes. The diagnosis of OA requires the presence of symptoms and signs that may include; joint pain, restriction of motion, crepitus with motion, joint effusions, and deformity (24). Although OA is most prevalent in the foot, knee, hip, spine, and hand joints (25-27), it can affect any synovial joint as well.

Osteoarthritis develops most frequently in the absence of a known cause (primary OA) and less often it develops as a result of a joint injury, infection or one of a variety of hereditary, developmental, metabolic and neurologic disorders (secondary OA). The age of onset associated with secondary OA depends on the underlying cause, thus, it may develop in young adults and even children as well as the elderly (28). In contrast, there is 
a strong association between the prevalence of primary osteoarthritis and increasing age. The tools to assess the prevalence of osteoarthritis have numerous limitations, including difficulty in defining and establishing the diagnosis and in evaluating more than a few synovial joints in each individual (25-27).

Biology of Articular Cartilage

\section{Composition of Cartilage}

Articular cartilage appears histologically to be a simple inert tissue and has a firm slick surface that resists deformation (29). Under the light microscope, the articular cartilage consists primarily of extracellular matrix, with only one type of cell, known as chondrocytes. Cartilage is a non-vascular tissue as it lacks blood vessels, lymphatic vessels, and nerves. In comparison with tissues such as muscle and bone, it has a low level of metabolic activity and appears to be less responsive to changes in loading or to injury (30-32). The morphology of articular cartilage shows that it has a highly intricate and ordered structure and that a variety of complex interactions between the chondrocytes and the protein matrix actively maintain the integrity of the tissue. The articular cartilage is composed of cells, water, and a matrix macromolecular framework, and it is this framework that provides the cartilage its mechanical properties $(30 ; 32)$. Chondrocytes make up about two percent of total volume of cartilage and hence they are considered a small part of the total volume of cartilage (33).

\section{Chondrocytes}

Within the articular cartilage, there is only one specialized type of cell known as chondrocyte $(29 ; 33)$. Chondrocytes from different locations of the articular cartilage 
differ in size, shape and activity (34). These cells contain organelles necessary for matrix synthesis and in some cases have short cilia extensions, which may play a role in sensing mechanical changes in the matrix. Chondrocytes are surrounded by extracellular matrix and do not form cell-to-cell contacts. These cells in their mature stage are spheroidal in shape and synthesize type II collagen, large aggregating proteoglycan, and specific noncollagenous proteins to form cartilaginous matrix $(34 ; 35)$. Individual chondrocytes are quite active metabolically but the total activity of the cartilage tissue is quite low due to the low cell density $(33 ; 35 ; 36)$.

In relation to the mechano-structural properties of the articular cartilage, chondrocytes appear to remain unchanged in location, appearance, and activity. The type of macromolecules that form the matrix and the concentration of water are important to the structural response of this tissue (37). Maintenance of the articular surface requires turnover of the matrix macromolecules, which involves the continuous replacement of degraded matrix components and alteration in the macromolecular framework of the matrix in response to the use of the joint (37). To achieve these activities, the chondrocytes must sense the changes in the matrix due to degradation as well as changes in macromolecules in relation to the demands placed on the articular surface (38). The cells respond by synthesizing appropriate types and amounts of the macromolecules (30).

\section{Structural Organization of Cartilage}

The primary function of the chondrocytes is to synthesize and organize collagens, proteoglycans and the non-collagenous proteins into unique and highly ordered matrix structure to form articular cartilage (30;32). The composition, organization, and mechanical properties of this matrix as well as the chondrocyte morphology and function 
vary according to the depth of the articular surface. These changes are identified in layers called zones and there are four zones known as superficial, transitional, middle (radial), and a zone of calcified cartilage (29). The zones differ in respect to their concentration of water, proteoglycan, and collagen including the size of the aggregates. Cells in these zones also differ in size, shape, and orientation relative to the articular surface (29). This also causes a variation in the degree of metabolic activity between the zones. Chondrocytes respond differently to mechanical loading which suggests that the development and maintenance of articular cartilage under normal conditions depends partly on the differentiation of the distinct populations of these cells across the zones $(30 ; 32)$.

\section{Pathogenesis, Clinical Features, and Risk Factors of OA}

Osteoarthritis is generally viewed as a degenerative disorder involving cartilage degradation in aging (39;40). Typically, the degenerative changes are accompanied by a local inflammatory component that may accelerate joint destruction $(39 ; 41)$. Hyaline articular cartilage is made up of a matrix of type II collagen fibers and proteoglycans, as well as the chondrocytes that produce the matrix, and water $(39 ; 42)$. In OA, the proteoglycan content of the cartilage is gradually depleted, leading to an initial increase in water content and a loss of compressibility and shock absorption, and culminating in fibrillation and breakdown (42).

The main clinical features of $\mathrm{OA}$ are pain, stiffness, loss of function, and ultimately joint deformity. Any of the joints may be affected in isolation or as part of primary generalized OA. The most common joints involved in OA include those of the knee, hands, feet, hips, and the apophyseal joints of the spine. OA is primarily a disorder 
of the hyaline articular cartilage that coats the bony surface of all synovial joints and the meniscus (43).

In addition to age, a number of other factors have been suggested as risk factors for the development of OA including: genetics, obesity, joint hypermobility, joint trauma, immobilization, peripheral neuropathy, crystals in joint fluid or cartilage, and repetitive joint overuse (13). The pathological processes and the radiological features vary to some degree across the different joints. Therefore, OA is generally considered to be a heterogeneous disorder and no two joints may be afflicted equally in the same individual. Predominance of generalized OA in women suggests that changes in production and nature of estrogens may be risk factors in the development of OA.

\section{Changes in the Diseased Joint}

\section{Morphological Changes}

Osteoarthritis involves all of the tissues that form the synovial joint, including articular cartilage, subchondral and metaphyseal bone, synovial tissue and ligaments, joint capsule, and muscles that surround the joint (44). However, the primary changes consist of loss of articular cartilage, remodeling of subchondral bone, and formation of osteophytes $(45 ; 46)$. The earliest histological changes in OA include the superficial zone of the articular cartilage and extend into the transitional zone $(47 ; 48)$. There is decreased staining for proteoglycans in these regions and protrusion of blood vessels from subchondral bone as a result of increased remodeling. Investigators suggest that the stiffening of subchondral bone due to this remodeling causes the degeneration of articular cartilage (47). Alternatively, the loss of articular cartilage could increase the level of

mechanical stress on the underlying bone, causing aggressive bone remodeling to occur 
(47). However, it is not certain as to what is the correct order of these events. But in most instances, the degeneration of articular cartilage and the remodeling of subchondral bone are both present when symptoms develop and it is this loss of cartilage that leads to the direct loss of joint function.

\section{$\underline{\text { Stages of Joint Degradation }}$}

Many of the mechanisms responsible for the progressive loss of cartilage in degenerative joint disease remain unknown. However, this process can be divided into three overlapping stages which include disruption or alteration of the cartilage matrix, the chondrocyte response to tissue damage, and the decline of the chondrocytic response to restore or maintain tissue leading to loss of articular cartilage $(21 ; 49)$ The first stage is when there is an overall disruption of the matrix framework and an associated increase in the concentration of water (50). The collagen meshwork may also be damaged and the degree of proteoglycan aggregation decreases (21). These changes proceed to the response of the chondrocytes in the second stage by increasing synthesis and decreasing the degradation of the matrix. Rate of degradation is controlled by the balance in activity between both anabolic and catabolic growth factors and cytokines (46).

In this second stage of the development of OA, the repair mechanisms may increase the synthesis of matrix macromolecules and to a lesser extent cell proliferation which can counter the catabolic effects and stabilize or in some instances restore the tissue (21). This repair response may continue for years and in some individuals reverse the course of osteoarthritis at least temporarily. The failure to stabilize or restore the tissue leads to the third stage in the development of OA $(46 ; 50)$. In the third stage, there is a progressive loss of articular cartilage as well as a notable decline in the anabolic 
response of the chondrocytes (51). This decline can result from mechanical insults and chondrocyte death which no longer can be supported by a stable and functional matrix (21). There is also a down-regulation of the chondrocytic response to anabolic growth factors and cytokines and an increase in synthesis and accumulation of molecules in the matrix such as catabolic cytokines and growth factor-binding proteins which decrease the overall anabolic effect (51). The loss of articular cartilage leads to the symptoms of pain and joint dysfunction associated with OA. This loss occurs most frequently with increasing age, possibly because age related changes in the cartilage matrix and the decrease in the chondrocytic anabolic response compromise the ability of the tissue to maintain and restore itself $(12 ; 21 ; 32)$.

\section{$\underline{\text { Proposed Role of Estrogen in Osteoarthritis }}$}

Epidemiologic studies have indicated that women over the age of 50 are the most vulnerable to joint disorders, especially OA. Sex hormones may play a role in the development of OA in women (52). The prevalence of OA increases in women following menopause and rises faster with age in women then in men (53-55). Tsai and colleagues (8) have suggested that excessive levels of synovial fluid estrogen are responsible for the development of OA in humans. In some animal studies, when estrogen was administered directly to the knee joint, it resulted in an increased frequency and severity of OA $(1 ; 2)$. Furthermore, Tsai and Lui (2) have shown that intraarticular injections of estradiol to ovariectomized rabbits induced an up-regulation of estrogen receptors in condylar cartilage at an early stage of OA and cartilage degeneration and erosion at the late stage. In OA, looser matrix might be synthesized in the medial compartment, allowing 
molecules in the synovial fluid, including estrogens to be taken up by the chondrocytes, and therefore resulting in cell death and cartilage erosion (2). Estrogen may affect articular cartilage by modulating the synthesis of the cartilage matrix and the production of matrix enzymes (56). Estrogen receptors are found in articular cartilage $(3 ; 57)$, but estrogen may also influence cartilage metabolism via cytokines (58). Estrogen has also been suggested to influence the development of OA through its effects on bone metabolism $(59 ; 60)$.

In partially menisectomized rabbits, estrogen accentuates the frequency and severity of OA. Estradiol also modulated articular cartilage metabolism by suppression of DNA and proteoglycan synthesis (56). Furthermore, intraarticular injection of estradiol to the knee joint impaired lactate dehydrogenase resulting in an overall disruption of matrix collagen (56) in cartilage tissue. These observations imply that estrogen can affect chondrocyte metabolism and proliferation, possibly through a receptor-mediated mechanism (56).

There are a number of epidemiological studies that have examined the possible relationship between estrogen replacement therapy (ERT) and risk of OA. Several investigators reported that women who at one time have been on ERT have a lower than expected risk of knee or hip OA (61-65). Prospective cohort investigation of the Framingham study indicated that the use of ERT had a moderate protective effect against worsening of radiographic knee OA among elderly women (66). Although evidence from these studies may suggest that estrogen protects against OA, there are important limitations to be considered. Women on ERT tend to be generally healthier, thinner and more active, as well as better educated than non-users. These characteristics as well 
others may benefit the estrogen users and make them less prediposed to have OA than the non-users. Currently there are no published clinical trials on ERT in OA. Longitudinal studies are needed in which estrogen users and non-users can be followed and carefully characterized for OA.

Estrogen may also play an important role in male OA. Higher synovial estradiol and higher estrogen receptor levels in cartilage of individuals with OA compared to nonOA may be primary reasons for the incidence of OA in males as well $(8 ; 57)$. The negative effects of estradiol in synovial fluid may be counterbalanced by endogenous testosterone, resulting in a lower estrogen/testosterone ratio or a lower unopposed, free estradiol to interact with cartilage.

\section{$\underline{\text { Estrogen Receptors and Selective Estrogen Receptor Modulators (SERM) }}$}

\section{Estrogen Receptors}

Estrogen has been shown to act genomically by coupling with the estrogen receptor and its coactivators to induce changes in gene expression. $17 \beta$-estradiol $\left(\mathrm{E}_{2}\right)$ and the estrogen receptors have been shown to form a ligand-estrogen receptor complex (67). The challenge in understanding the mechanisms by which estrogen exerts its effects is due to the existence of its two receptor subtypes, estrogen receptor (ER)- $\alpha$ and ER $\beta$. The two receptors share considerable homology but differ in the C-terminal ligand binding domain and its N-terminal transactivation domain (68). Paech and colleagues (67) have demonstrated that the transcriptional effects elicited by $E_{2}$ are determined by whether or not it interacts with $\mathrm{ER} \alpha$ or $\mathrm{ER} \beta$. The two receptors exhibit different responses to drugs such as tamoxifen and raloxifene which are categorized as either anti-estrogens or SERM. While estrogen induces negative transcription regulation, SERM induce positive 
regulatory sequences when interacting with ER $\beta$. This may explain, in part, how SERM are able to induce beneficial estrogenic effects on bone and cardiovascular without dramatically increasing the risk of cancer of the reproductive organs.

\section{Tissue Specific Actions of SERM}

The levels of expression for each ER subtype vary from organ to organ, and bind estrogen with varying affinity. The ratio of $\mathrm{ER} \alpha$ to $\mathrm{ER} \beta$ in different vascular beds vary and this may explain the different responses exerted by SERM in various tissues (69). The two well known SERM, tamoxifen and raloxifene, are non-steroidal phenylethylene derivatives that have been shown to bind to ER $\beta$ with higher affinity than ER $\alpha$ (70). In some cases, SERM mimic the effects of estrogen, while in other cases, antiestrogenic effects are observed (70). They were first characterized as antagonists/partial agonists on the basis of their binding to ER $\alpha$. However since then they have been shown to act as full estrogen agonists in bone through their interaction with ER $\beta$. The differential estrogenic effects of SERM vary, as tamoxifen has been shown to have estrogenic actions in the uterus, while raloxifene does not (70). Thus the acronym SERM takes into account the selective modulations of the ER in specific tissues (70). The selective action of both natural and synthetic SERM and their interaction with each of the ER subtype across different tissues needs to be further investigated.

Role of Cytokines and Growth Factors in OA

\section{Function}

Cytokines and growth factors are released by cells in response to specific signals 
and influence the function of target cells by exerting a positive or negative effect on gene expression (71). Because they have a relatively short half-life, they usually exert their influence on cells in the local environment. Cytokine production and its effects on target cells are regulated in several ways. Homeostasis is maintained as a balance between a particular cytokine and various naturally occurring molecules that function as cytokine inhibitors (71). The cartilage tissue is maintained by the equilibrium between the effects of catabolic cytokines (e.g. IL- $1 \alpha$ and $\beta$, TNF- $\alpha$ ) which induce the production of specific matrix degrading metalloproteases, and anabolic growth factors such as insulin-like growth factor and transforming growth factor- $\beta$ which induce the production of building blocks of cartilage such as collagen and proteoglycans (71).

In osteoarthritis, the breakdown of the joint tissue occurs in several phases (72). This depletion suggests an overall failure in the cytokine-controlled matrix homeostasis, with a shift in equilibrium between synthesis and degradation favoring catabolic processes. In the earlier stages of OA, the chondrocytes attempt to repair the cartilage by increasing the synthesis of matrix macromolecules (50). The increased presence of anabolic growth factors presumably activates the chondrocytes to stimulate the matrix synthesis. However, compositional change in the matrix molecules may interfere with this process by reducing their capacity to aggregrate properly with hyaluronic acid (73). Over time, the matrix losses its resiliency and fails to withstand the mechanical stress placed on the joints. In the later stages of the disease process, enhanced cartilage degradation far exceeds the ability of the chondrocytes to synthesize new matrix. Furthermore, there is increased presence of catabolic cytokines such as IL-1 $\beta$ and TNF$\alpha$ that potentiate the expression of matrix metalloproteinases causing proteolysis of the 
cartilage matrix (74). These factors can also inhibit cartilage matrix biosynthesis (75).

Evidence is accruing to implicate cytokines in the pathogenesis of joint diseases with major inflammatory and autoimmune components (76). However the mechanisms that initiate and cause cartilage destruction in osteoarthritis remain unclear. The profile for cytokines and growth factors based on quantitative rather than qualitative differences as indicated by fewer cells being recruited for their production in osteoarthritis. This may suggest that other processes are involved in cartilage destruction, and that cytokines are merely indicators of the disease activity. However, the involvement of cytokines and growth factors is a topic of interest in relation to their function in cartilage integrity.

\section{Catabolic Cytokines}

Interleukin-1 (IL-1 $\beta$ ) was first identified as an inflammatory mediator capable of tissue damage. Its importance in cartilage metabolism appears to be a result of its ability to suppress the synthesis of type II collagen, the predominant form of collagen found in articular cartilage (72). Furthermore, IL-1 $\beta$ is shown to stimulate synthesis of type I collagen, which is predominant in fibroblasts $(77 ; 78)$. The increased presence of IL-1 $\beta$ and the formation of fibroblasts suppresses the ability of chondrocytes to synthesize new proteoglycan, a building block in cartilage formation (79). For cartilage degradation to occur, catabolic cytokines such as IL-1 $1 \beta$ must act at specific receptors on the target cells (77;79). In osteoarthritis, there is increased presence and sensitivity of IL-1 $\beta$ receptors to interact with IL-1 $\beta$ and trigger the joint destruction processes.

The potency for cartilage breakdown is 10 -fold less in the case of tumor necrosis factor (72). Apparently, both IL-1 $\beta$ and TNF- $\alpha$ are produced by the same cells under the 
same stimuli. However, in osteoarthritis, the two cytokines are not significantly correlated during active disease(72).

\section{Markers of Cartilage Degradation}

A specific marker for cartilage metabolism that is secreted by cultured chondrocytes is human cartilage glycoprotein 39 (YKL-40). The name is derived from its 40 kilodalton molecular weight and the one-letter code for its 3-N-terminal amino acids; tyrosine, lysine, and leucine (80). YKL-40 is synthesized by articular chondrocytes (8183) and synovial cells (84) in patients with both RA and OA. Histological specimens obtained from patients with OA have shown positive staining for YKL-40 in chondrocytes mainly in the superficial and middle zones of the cartilage whereas it was low or undetectable in normal cartilage samples (83). Elevated levels of both serum and synovial fluid YKL-40 are seen in patients with active RA or severe knee OA in comparison to normal subjects $(80)$. Johansen and colleagues $(80 ; 85)$ demonstrated that YKL-40 was produced in response to removal of chondrocytes from their native extracellular matrix environment related to joint injury and disruption of the cartilage framework. YKL-40 production may be mediated by cytokines and growth factors that have a regulatory effect on chondrocyte function, especially in inflammatory conditions of the joints such as OA.

\section{Current Treatments and Therapies for OA-Medications}

\section{Classes of Non-Steroidal Anti-Inflammatory Agents}

The choice of effective treatments for individuals with $\mathrm{OA}$ is quite a challenge.

The consensus recommendation for patients with $\mathrm{OA}$ has been to use acetaminophen 
(86). Study by Fries and colleagues (87), compared the effects of various doses of acetaminophen with ibuprofen in patient with RA and OA. Overall, their finding indicated that those who took acetaminophen had better tolerability less pain and less gastrointestinal distress in comparison with ibuprofen. Acetaminophen is an excellent analgesic but does not possess any anti-inflammatory activity $(86 ; 87)$. Its mechanism of action is not clearly known but it has been shown to inhibit prostaglandin synthesis at higher doses (88). The adverse effects with the use of acetaminophen have been due to acute overdose which is associated with liver damage. Furthermore, in a case-controlled study, chronic use can lead to kidney failure in some individuals (27).

\section{Celecoxib and Rofecoxib}

The new class of non-steroidal anti-inflammatory drugs (NSAIDs) has shown vastly improved function in $\mathrm{OA}$ and rheumatoid arthritis patients with similar efficacy to their predecessors but with significantly decreased gastrointestinal and platelet effects $(89 ; 90)$. Americans use these agents on a daily basis and according to the projected statistics by the US Center for Disease Control and Prevention, it is likely that a significant increase in the prevalence of painful and degenerative conditions will likely increase the use of NSAIDs (91). The newer class of NSAIDs selectively inhibit COX-2 more so then COX-1. This makes them more potent anti-inflammatory agents for degenerative joint conditions such as OA without causing detrimental effects on the gastrointestinal tract.

The most commonly used therapeutic compounds for OA in this class are called celecoxib and rofecoxib (92). Both of these compounds are selective COX-2 inhibitors 
and have been shown to be effective in reducing or alleviating OA pain and inflammation associated with rheumatoid arthritis (90;93-96). These studies also presented clear evidence of no endoscopic gastroduodenal damage and no adverse effect on platelet aggregation (89; 90;92-96). However, many of these studies have left the renal effects of these potent COX-2 inhibitors unanswered. Several mechanisms being proposed for these anti-inflammatory compounds include their in vitro inhibition of inducible nitric oxide synthase which subsequently decreases the production of nitrite $(49 ; 97)$. It has also been suggested that NSAIDs, by inhibiting prostaglandin production could also be responsible in reestablishing a more normal cell cycle response which is inhibited by prostaglandins (98-100). Longer-term effects of these agents are not yet fully understood in context of their toxic load on the liver as well as their adverse effects on other tissues and organ systems.

\section{$\underline{\text { Role of Soy Isoflavones in OA }}$}

There is evidence that flavonoids (10), in particular isoflavones, may exert beneficial effects on cartilage metabolism. Soy isoflavones have been shown to exert positive effects on cardiovascular (101)and skeletal health (102). These beneficial effects of isoflavones, in part, may be mediated through their anti-inflammatory properties(6). Studies (6) have suggested that plant flavonoids attenuate inflammation and the immune response through their inhibition of important regulatory enzymes involved in arachidonic acid metabolism. Flavonoids are powerful inhibitors of both lipoxygenase (LOX) and COX-2 activities (6). Lin and colleagues reported that flavonoids are inhibitors of IL-1 $\beta$, IL-6, TNF- $\alpha$, and COX-2. They also found that flavonoids downregulated matrix metalloproteinases (MMP), while upregulating MMP inhibitor in 
human synovial fibroblasts. Flavonoids may thus inhibit the inflammation response through these modes of action, suggesting that this class of molecules may be effective in conditions such as OA.

Genistein, the prominent soy isoflavone, is structurally similar to tamoxifen and ipriflavone, a synthetic isoflavone(10). Tamoxifen (6) and ipriflavone (10) have both been shown to influence cartilage metabolism and reduce or alleviate the symptoms associated with OA. 


\section{CHAPTER III}

\section{MATERIALS AND METHODS}

\section{Experimental Design}

Pure human chondrocytes were purchased from PromoCell Bioscience Alive (Heidelberg, Germany). Chondrocytes were recovered and plated in complete chondrocyte growth medium (PromoCell, Heidelberg, Germany) with $10 \%$ fetal calf serum at $37{ }^{\circ} \mathrm{C}$ in a $5 \% \mathrm{CO}_{2}$ humidified incubator in 6 well plates $(\mathrm{n}=3)$. Genistein (Sigma, St Louis, MO) and, ICI 182,780 (Tocris, Northpoint, UK) were dissolved in dimethylsulfoxide and added directly to the culture media in various doses of genistein $(0,50$, and $100 \mu \mathrm{M})$ and $100 \mu \mathrm{M}$ ICI when cells were $80 \%$ confluent. Control cells were treated only with solvent. After one hour, $1 \mu \mathrm{g} / \mathrm{ml}$ LPS (Sigma Diagnostics, St Louis, MO) was added to all treated, except the control $(\mathrm{CON})$ cells. Nitric oxide production in cell culture medium and protein levels of COX-2 and COX-1 in cytosolic fraction were measured.

To compare the effect of genistein to that of NS-398 (Cayman chemical, Ann Arbor, MI, U.S.A.), a COX-2 inhibitor, chondrocytes were plated in 6 well plates $(n=4)$ and treated with different doses of genistein $(0,50$ and, $100 \mu \mathrm{M})$ and $10 \mu \mathrm{M}$ NS-398 when cells were $80 \%$ confluent. After one hour, $1 \mu \mathrm{g} / \mathrm{ml}$ LPS was added to all the treatment groups, except the control (CON) group. IL-1 $\beta$ and YKL-40 was measured in cell culture medium. 


\section{Cell Viability Assay}

Chondrocytes were plated in 96 wells in density of 15,000 cells/well in phenol red free medium and kept overnight. Cells were treated with different doses of genistein $(0$, $25,50,100$ and $200 \mu \mathrm{M})$ and one dose of NS-398 $(10 \mu \mathrm{M})$. After one hour incubation at $37^{\circ} \mathrm{C}$ in $5 \% \mathrm{CO}_{2}$, chondrocytes were treated with $1 \mu \mathrm{g} / \mathrm{ml}$ LPS for 24 hours. Culture medium was removed and $200 \mu \mathrm{L}$ culture medium containing 10\% resazurin (Sigma, Saint Louis, MO) was added to wells. Cells were incubated at $37^{\circ} \mathrm{C}$ in $5 \% \mathrm{CO}_{2}$ for 4 hours. The absorbance was measured at reference wavelength of $690 \mathrm{~nm}$ and subtracted from the $600 \mathrm{~nm}$ measurement. The number of cells was determind as a function of metabolic activity using the dye resazurin according to the manufacture's directions.

\section{$\underline{\text { Western Immunoblotting }}$}

Chondrocytes cultures when reached $80 \%$ confluency were washed with phosphate buffer saline (PBS) twice. $300 \mu \mathrm{L}$ of lysing buffer $(100 \mathrm{mmol} / \mathrm{L}$ HEPES, pH 7.9; $100 \mathrm{mmol} / \mathrm{L} \mathrm{KCL;} 100 \mathrm{mmol} / \mathrm{L}$ EDTA, $100 \mathrm{mmol} / \mathrm{L}$ DTT, protease inhibitor cocktail and $10 \%$ IGEPAL) was added to each plate then plate was incubated on ice and shook at $150 \mathrm{rpm}$ on a rocking platform for $10 \mathrm{~min}$. Cells were then collected and centrifuged at $15000 \times \mathrm{g}$ for 3 minutes at $4{ }^{\circ} \mathrm{C}$. Supernatant of cytosolic fraction was collected and stored at $-80{ }^{\circ} \mathrm{C}$. For protein concentration measurement, $200 \mu \mathrm{L}$ mixture of bicinchoninic acid and copper (49:1) was added into $5 \mu \mathrm{L}$ cytosolic fraction using a 96 well-plate. Plate was then covered by an aluminum foil and incubated at room temperature for 20 minutes mildly being shaken using a belly dancer (Stovall Life Science, Greensboro, NS). Absorbance was measured at wavelength of $570 \mathrm{~nm}$. Equal 
amounts of protein $(20 \mu \mathrm{g})$ was brought to volume of $12 \mu \mathrm{L}$ by adding autoclave water, mixed with $12 \mu \mathrm{L}$ loading buffer $(0.125 \mathrm{~mol} / \mathrm{LTris}, 4 \%$ sodium dodecyl sulfate (SDS), $20 \%$ glycerol, $10 \%$ 2-mercaptoethanol, $0.003 \%$ bromophenol blue $\mathrm{pH} 6.8$ ) and heated at 95-100 ${ }^{\circ} \mathrm{C}$ for 5 minutes. Protein was separated on $8 \%$ SDS-polyacrylamide gel for $2 \mathrm{hrs}$ (100v), and transferred to polyvinylidene diflouride (PVDF) membrane (Millipore, Bedford, MA) by using a semi-dry blotting apparatus for one hour (15v). Membrane was blocked with Tris-buffered saline (TBS, 8mmol/L Tris HCL, 16mmol/L Tris-base, $150 \mathrm{mmol} / \mathrm{LNaCl}$ ) containing $5 \%$ skim milk for one hour. After washing in TBS, blots were incubated overnight with a 1:200 dilution of COX-2 and COX-1 (Santa Cruz Biotechnology, CA) antibody overnight. This was followed by a 2-hour incubation with 1:2000 dilution of goat polyclonal antibody and rabbit polyclonal antibody (Santa Cruz Biotechnology, CA) in blocking buffer. The protein bands were visualized using an Immun-Star HRP substrate kit (Bio-Rad laboratories, Hercules, CA). Membrane was covered by $2 \mathrm{~mL}$ of immuno-star HRP peroxide buffer mixed by $2 \mathrm{~mL}$ immuno-star horse radish peroxidase (HRP) enhancer and visualized using VersaDoc Imaging System (Bio-Rad laboratories, Hercules, CA).

\section{Nitric Oxide Assay}

Nitric oxide (NO), an important physiological messenger in local inflammation, was measured by Griess reagent system (Promega Co. Madison, WI) in culture medium . This reagent can measure nitrite $\left(\mathrm{NO}_{2}{ }^{-}\right)$, which is one of the two primary, stable and nonvolatile breakdown products of NO. Chondrocytes were plated in 96 wells in density of 15000 cells/well in phenol red free medium and kept overnight at $37^{\circ} \mathrm{C}$ incubator 
under $95 \% \mathrm{O}_{2}, 5 \% \mathrm{CO}_{2}$. Cells were treated with different doses of genistein $(0,50$ and, $100 \mu \mathrm{mol} / \mathrm{ml} \mathrm{medium})$ and one dose of ICI (100 $\mu \mathrm{mol} / \mathrm{ml}$ medium $)$. After one hour incubation at $37^{\circ} \mathrm{C}$ in $5 \% \mathrm{CO}_{2}$, chondrocytes were treated with $1 \mu \mathrm{g} / \mathrm{ml}$ LPS for 24 hours. Fifty $\mu \mathrm{L}$ of each collected culture supernatant and nitrate standards $(0,0.0935,0.187$, $0.375,0.75,1.5$ and, $3 \mu \mathrm{M})$ were added to 96 well plates. $50 \mu \mathrm{L}$ medium containing $10 \%$ sulfanilamide was added into each well and then incubated for 10 minutes at room temperature away from light. Then $50 \mu \mathrm{L}$ of $0.1 \% \mathrm{~N}$-1-napthylethylenediamine dihydrochloride was added to each well and incubated 10 minutess at room temperature in dark. Absorbance was measured within 30 mins in a plate reader with a filter between 250-550 nm.

\section{$\underline{\text { Aseessement of IL-1 } 1 \beta}$}

Interleukin-1 $\beta$ was measured in culture medium with enzyme-linked immunosorbent assay (ELISA) ( PromoKine Bioscience Alive, Germany) which is designed to measure free cytokines in tissue cell culture supernatants. Standards (1000, $500,125,31.25,7.81$ and, $0.0 \mathrm{pg} / \mathrm{mL}$ ) and samples were added to monoclonal antibodies precoated microtiter plates in quantity of $100 \mu \mathrm{L}$. Twenty five $\mu 1$ of rabbit anti-human IL$1 \beta$ polyclonal antibody were added into each well. After 3 hours incubation at room temperature, plate was washed with phosphate buffer saline buffer four times. Fifty $\mu \mathrm{L}$ goat anti-rabbit conjugated alkaline phosphatase was added into wells followed by 45 minutes incubation at room temperature. Plate was washed 4 times with buffer and then $200 \mu \mathrm{L}$ of color reagent solution was dispensed into each well. The reaction was stopped after 15 minutes incubation at room temperature by adding $50 \mu \mathrm{L}$ stop solution into each 
well. Absorbance was read at $492 \mathrm{~nm}$ and values were reported as $\mathrm{pg} / \mathrm{mL}$.

\section{$\underline{\text { YKL-40 EIA Kit }}$}

YKL-40, also known as human cartilage glycoprotein 39, a marker of tissue remodeling, produced by chondrcoyets (Hakala BE et al., 1993) was measured by enzyme immunoassay (EIA) kit ( Metra, Quidel Co., San Diego, CA) using aliquots of cell culture supernatant. This is a sandwich enzyme immunoassay in a microtiter stripwell format. Twenty $\mu \mathrm{L}$ of cell culture media and standard (0.0, 50, 100, 200 and $300 \mathrm{ng} / \mathrm{mL}$ ) was added to each streptavidin coated well. The fabricate's fragments of a monoclonal anti-YKL-40 antibody conjugated to biotin binds to striptavidin on the strip and captures YKL-40 in standards and samples. After one hour of incubation at room temperature, the plate was washed with a buffer containing sodium azide (0.05\%). 100 $\mu \mathrm{L}$ of polyclonal anti YKL-40 antibody conjugated to alkaline phosphatase was added to each well to bind to the captured YKL-40, followed by one hour incubation at room temperature and washing with buffer containing sodium azide $(0.05 \%)$. Then $100 \mu \mathrm{L}$ of a diethanolamine and magnesium chloride solution containing sodium azide $(0.05 \%)$ and p-nitrophenyl phosphate was added to each well and incubated at room temperature for another hour. Bound enzyme activity was detected with p-nitrophenyl phosphate as substrate and the reaction was stopped with $100 \mu \mathrm{L} 1 \mathrm{~mol} / \mathrm{L} \mathrm{NaOH}$. The absorbance was read at $405 \mathrm{~nm}$ with a microplate reader and values were reported as $\mathrm{ng} / \mathrm{mL}$.

\section{$\underline{\text { Statistical Analysis }}$}

Data were analyzed using Student t-test, SAS Version 8.2 ( SAS Institute, Cary, 
NC) and are presented as mean \pm standard error (SE). Significant differences were determined using alpha level of 0.05 . 


\section{CHAPTER IV}

\section{RESULTS}

\section{Cell Viability}

Treatment with LPS $(1 \mu \mathrm{g} / \mathrm{ml})$, genistein in doses of $0,25,50,100,200 \mu \mathrm{M}$, and NS-398 $(10 \mu \mathrm{M})$ did not negatively affect the viability of chondrocytes (Figure I). Data are presented as percent of viable cells.

\section{$\underline{\text { Protein Level of COX-2 and COX-1 }}$}

LPS significantlyincreased the protein level of COX -2 in chondrocytes while genistein decreased the protein level of COX-2 by $8.36 \%$ in $50 \mu \mathrm{M}$ dose and significantly $(P<0.05)$ decreased the COX-2 level protein by $31.8 \%$ in $100 \mu \mathrm{M}$ dose. ICI 182,780

decreased COX-2 protein level but not significantly (Figure II). Genistein treatment had no effect on COX-1 protein level (Figure III).

\section{$\underline{\text { Nitric Oxide Production }}$}

Nitric oxide level in cell culture supernatant tended to increase as a result of LPS treatment (Figure IV). Interestingly, LG50 was more effective in reducing NO production than LG100 (42\% vs. 28\%) in comparison with LPS-treated control cells. ICI had no effect on NO production. 


\section{$\underline{\text { Interleukin-I Beta Production }}$}

IL-1 $\beta$ mean values were numerically lower in genistein-treatment groups by 36.4 $\%$ and $48 \%$ for both doses of 50 and $100 \mu \mathrm{mol} / \mathrm{ml}$ genistein, respectively in comparison with LPS-treated group. Overall, there were no significant differences among the treatment groups (Figure V). These findings indicate that larger sample sizes may be necessary in order to detect significant differences as a result of treatments which were applied in the present study.

\section{$\underline{\text { YKL-40 Production }}$}

YKL-40, a marker of human cartilage glycoprotein degradation, increased in LPS-treated group. Both doses of genistein were able to suppress its levels in cell supernatant by 18.6 $\%$ and $29.3 \%$ respectively for LG50 and LG100 compared to LPS-treated group but not significantly. Vi® had no effect on YKL-40 production (Figure VI). 


\section{CHAPTER V \\ DISCUSSION}

The finding of the present study indicate that genistein, a soy isoflavone, suppress the production of proinflammatory molecules such as COX-2, NO and IL-1 $\beta$ in LPSinduced chondrocytes whileit has no effect on COX-1 production. These findings supporting our earlier study (7) which shows that $40 \mathrm{~g}$ soy protein containing $88 \mathrm{mg}$ isoflavone daily for three months improved OA associated symptoms such as range of motion of the knee joint and several factors associated with pain and quality of life. Isoflavones are thought to act similar to estrogen, possibly through estrogen-receptormediated events. Soy isoflavones are referred to as natural SERMs (6) because of their conformational ability to bind to estrogen receptor s (ERs), particularly the beta subtypes (68), in a manner similar to other SERMs such as raloxifene. To test this hypothesis we used ICI-182, 780, an estrogen receptor anatagonist, to block the estrogen receptor and inhibit the action of genistein through estrogen receptors. Results showed thatgenistein suppresses the protein level of COX-2, in part, through estrogen receptors. However, several discrete signaling pathways have been implicated in the genesis of COX-2 synthesis that is dependent on the stimulus imposed on cells. Several studies have shown

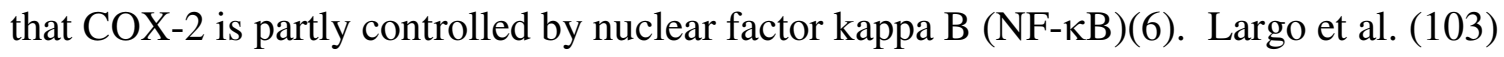
have shown that inhibition of $\mathrm{NF}-\kappa \mathrm{B}$ activation was related to the down regulation of the expression and synthesis of COX-2. COX is a critical proinflammatory enzyme that 
converts arachidonic acid to prostaglandins. Although prostaglandins have been implicated in the pain and inflammation associated with osteoarthritis (104), they may not fully explain either joint inflammation nor OA symptoms. Nonsteroidal antiinflammatory drugs (NSAIDs) or COX- inhibitors have been extensively used in the treatment of OA $(105 ; 106)$. It has been suggested that the antiinflammatory action of NSAIDs are due to inhibition of COX-2, a cytokine-induced isoenzyme that mediate pain and inflammation, whereas the unwanted side effects such as the risk of significant injury to the upper gastrointestinal tract and lining of kidneys (107) are due to inhibition of COX-1 (106). Interestingly, in the present study genistein dose-dependently decreased the production of COX-2 protein level while it had no such an effect on COX 1.

Other proinflammatory cytokines such as IL- $1 \beta$ and TNF- $\alpha$, are believed to cause damage to cartilage by inducing matrix metalloproteinase (MMP) expression in chondrocytes $(73 ; 108 ; 109)$. Both cytokines activate synthesis and release of MMPs which leads to matrix breakdown (46). Elevated levels of IL-1 $\beta$ are also found in OA synovial fluid and gene expression of IL-1 $\beta$ has similarly been reported to be upregulated in cartilage obtained from patients with knee OA (50).

While the findings of the present study indicate that genistein non-significantly reduces LPS-induced I $¥ \beta$ in chondrocytes in a dose-dependent manner, these reductions can not be due to cytotoxicity as any of the doses of genistein had no effect on cell viability. Interleukin-1 $\beta$ has been shown to induce production of NO in synovial cells and chondrocytes, which leads to increased vasodilation, permeability, and cartilage resorption in arthritic joints (110). Additionally, NO inhibits proteoglycan synthesis, modulates the activity of metalloproteines, and induce apoptosis in human chondrocytes 
(111). Although in non cell cultural experimental models of inflammation and arthritis NO has been shown to either promote or prevent tissue injury (110), in chondcrocytes NO has been demonstrated to inhibit collagen and proteoglycan synthesis (110) and induce apoptosis (112). Hence, our finding that genistein suppresses the production of NO should viewed as a positive finding.

YKL-40, a marker of cartilage degradation, was numerically increased in LPStreated chondrocytes, albeit not significantlyin the present study . Elevated serum YKL40 levels are associated with increased cartilage breakdown (85), which is often triggered by inflammation. Immunohistochemical analysis of articular cartilage biopsy samples from the hip joint of patients with OA have shown positive staining for YKL-40 in chondrocytes. YKL-40 is synthesized by articular chondrocytes (81) of patients with OA or RA. The findings of a study by Volck B. et al. (83) indicated that YKL-40 expression in chondrocytes from normal cartilage was low or not detectable in comparison with patients with OA. In another study by Volck et al., (85) YKL-40 was detected in the inflamed synovial membrane and the number of YKL-40 positive cells were associated with the degree of synovial inflammation.

Athough both doses of 50 and $100 \mu \mathrm{M}$ genistein numerically decreased the YKL40 levels in LPS-induced chondrocytes by $18.56 \%$ and $29.31 \%$, respectively, in comparison with LPS-treated cells, these values did not reach significance. It can be speculated that if our sample size was larger the differences would have become significant. The notion of anti-inflammatory effect of genistein can be indirectly supported by observations of Volck et al. (85) who injected human arthritic joints with glucocorticoid and noticed remission in joint inflammation followed by a decrease in 
serum YKL-40.

In summary, the results of the present study show that genistein selectively decreases the production of LPS- induced COX-2 protein level in chondrocytes without affecting COX-1. If the results are shown to be reproducible, genistein can be of particular interest to individuals who suffer from chronic inflammatory conditions such OA. As discussed earlier, there are no pharmaceutical agents that selectively can inhibit COX-2 production without having serious side effects. Therefore, Genistein decreased LPS-induced NO production in chondrocytes though not in a dose-dependent manner. Genistein also numerically decreased IL-1 $\beta$ and YKL-40. 


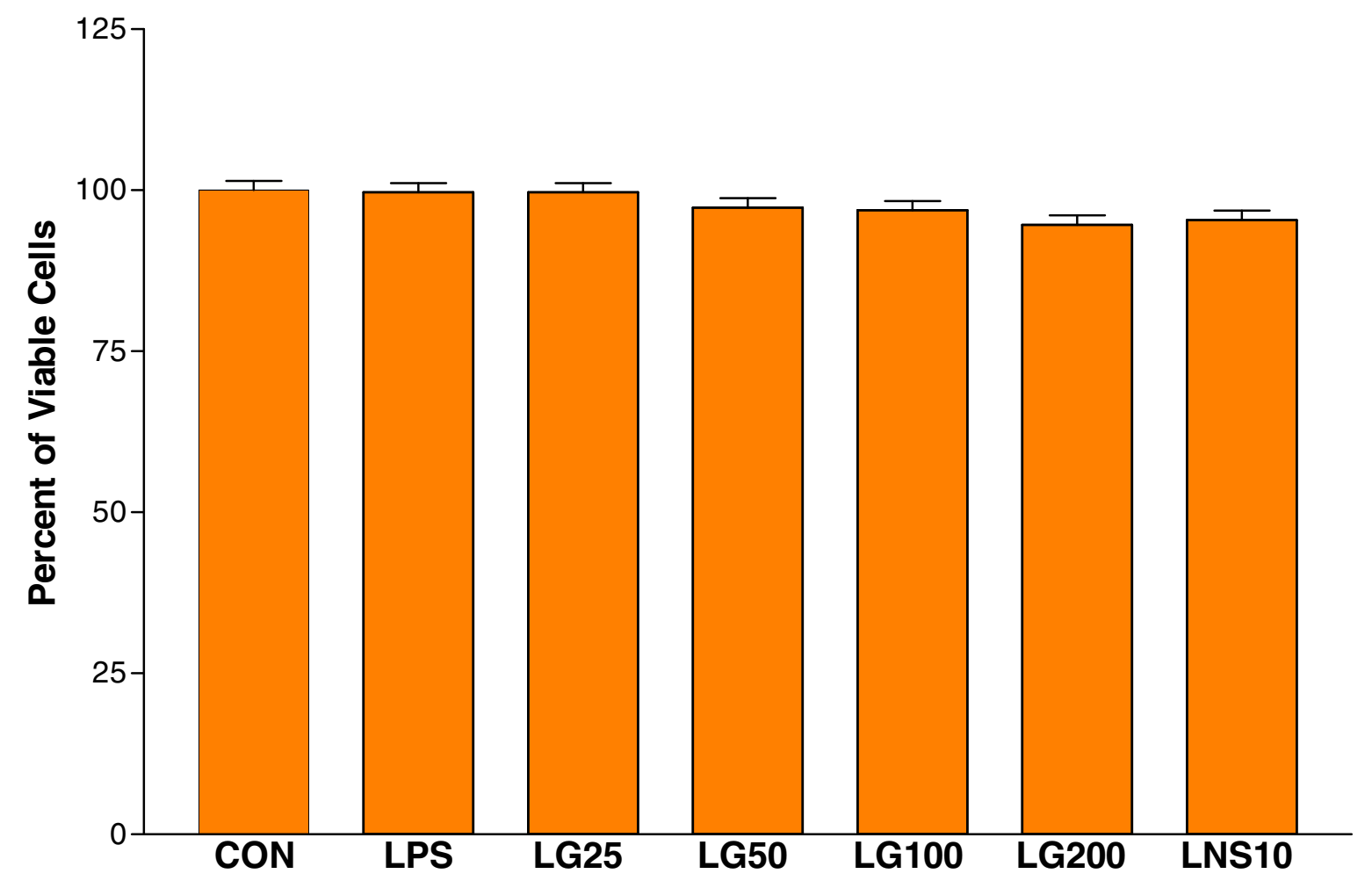

Figure 1. Represents cell viablelity which was measured via resazurin method. CON, control without added lipopolysaccharide; LPS, $1 \mu \mathrm{g} / \mathrm{mL}$; LG25, $25 \mu \mathrm{M}$ genistein; LG50, $50 \mu \mathrm{M}$ genistein; LG100, $100 \mu \mathrm{M}$ genistein; LG200, $200 \mu \mathrm{M}$ genistein; and LNS10, 10 $\mu \mathrm{M}$ Viox. All treatment groups were treated with $1 \mu \mathrm{g} / \mathrm{mL}$ LPS. Bars represent mean \pm $\mathrm{SE}, \mathrm{n}=4$ per treatment group. 


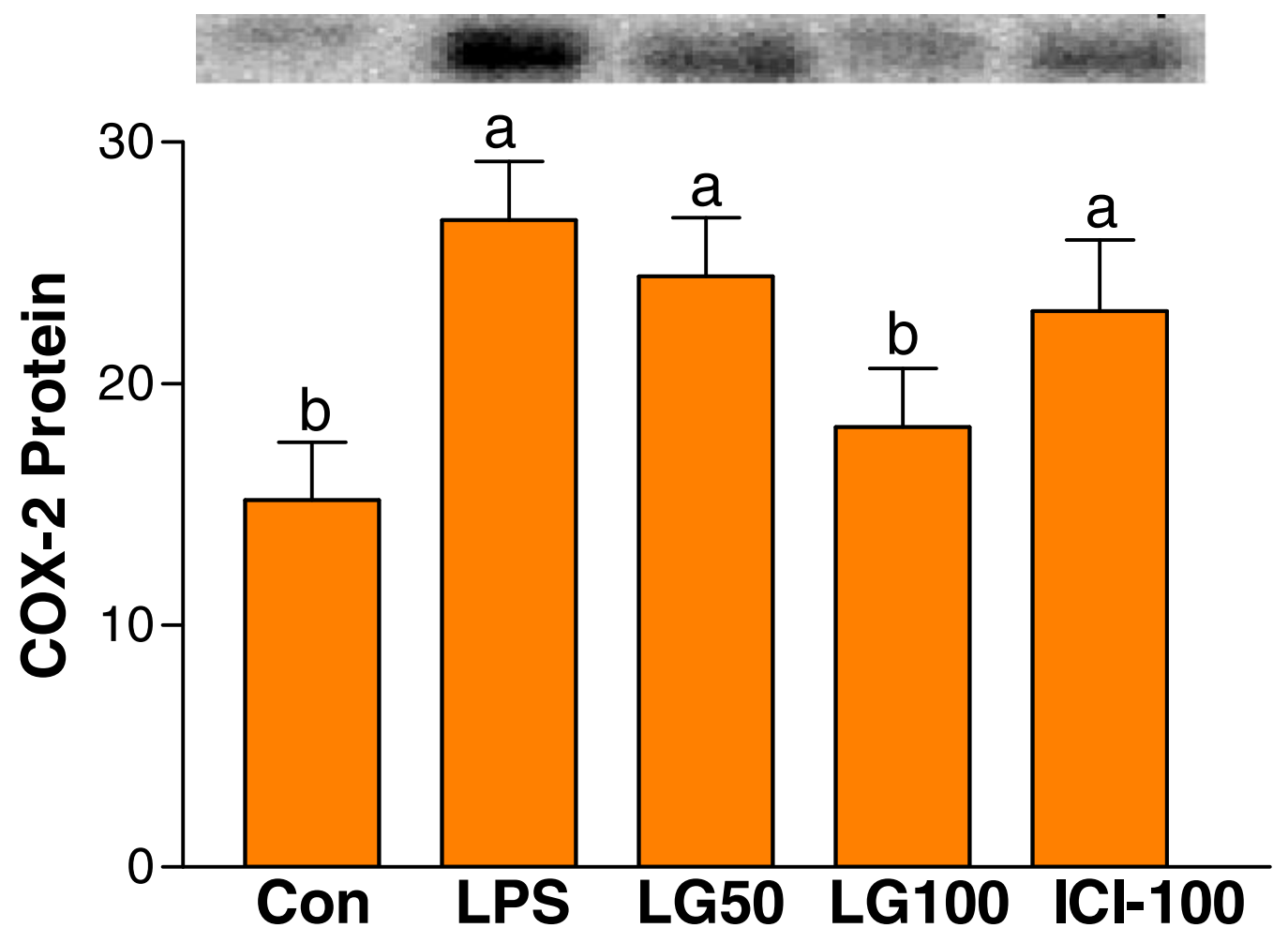

Figure 2. Represent protein level of COX-2 in cytosolic fraction of chondrocytes which was measured via westernblot method. CON, control without added lipopolysaccharide; LPS, 1 $\mu \mathrm{g} / \mathrm{mL}$; LG25, $25 \mu \mathrm{M}$ genistein; LG50, $50 \mu \mathrm{M}$ genistein; LG100, $100 \mu \mathrm{M}$ genistein; LG200, $200 \mu \mathrm{M}$ genistein; and ICI-100, $100 \mu \mathrm{M}$. All treatment groups were treated with $1 \mu \mathrm{g} / \mathrm{mL}$ LPS. Bars represent mean $\pm \mathrm{SE}, \mathrm{n}=3$ per treatment group. Bars with different letters are significantly different $(P<0.05)$. 


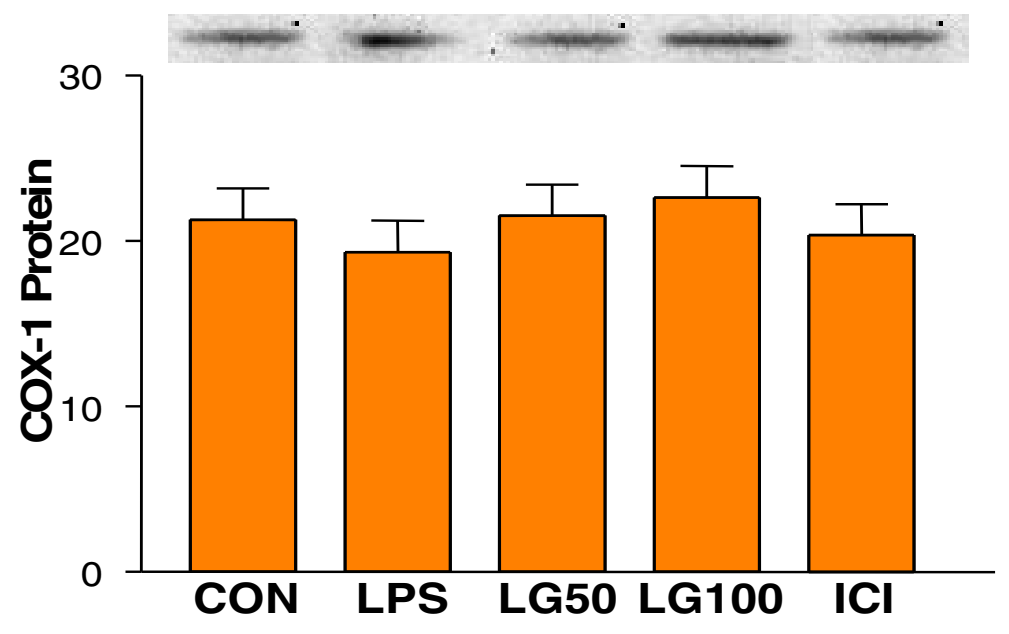

Figure 3. Represent protein level of COX-1 in cytosolic fraction of chondrocytes which was measured via westernblot method. CON, control without added lipopolysaccharide; LPS, 1 $\mu \mathrm{g} / \mathrm{mL}$; LG25, $25 \mu \mathrm{M}$ genistein; LG50, $50 \mu \mathrm{M}$ genistein; LG100, $100 \mu \mathrm{M}$ genistein; LG200, $200 \mu \mathrm{M}$ genistein; and ICI-100, $100 \mu \mathrm{M}$. All treatment groups were treated with $1 \mu \mathrm{g} / \mathrm{mL}$ LPS. Bars represent mean \pm SE, $\mathrm{n}=3$ per treatment group. 


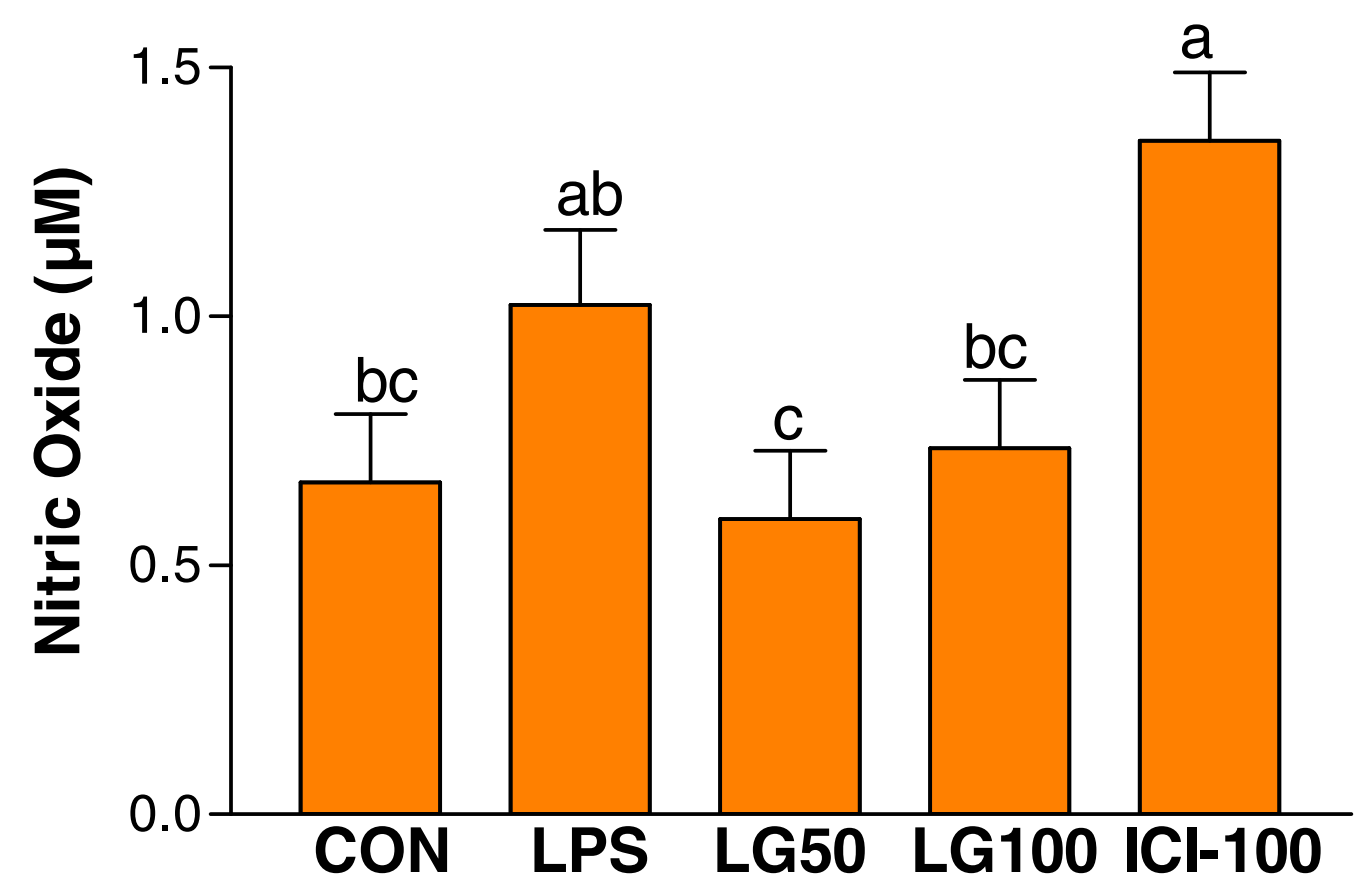

Figure 4. Represents NO level in culture supernatant which was measured via griess reagent. CON, control without added lipopolysaccharide; LPS, $1 \mu \mathrm{g} / \mathrm{mL}$; LG25, $25 \mu \mathrm{M}$ genistein; LG50, $50 \mu \mathrm{M}$ genistein; LG100, $100 \mu \mathrm{M}$ genistein; LG200, $200 \mu \mathrm{M}$ genistein; and LNS10, $10 \mu \mathrm{M}$ Viox. All treatment groups were treated with $1 \mu \mathrm{g} / \mathrm{mL}$ LPS. Bars represent mean $\pm \mathrm{SE}, \mathrm{n}=3$ per treatment group. Bars with different letters are significantly different $(P<0.05)$. 


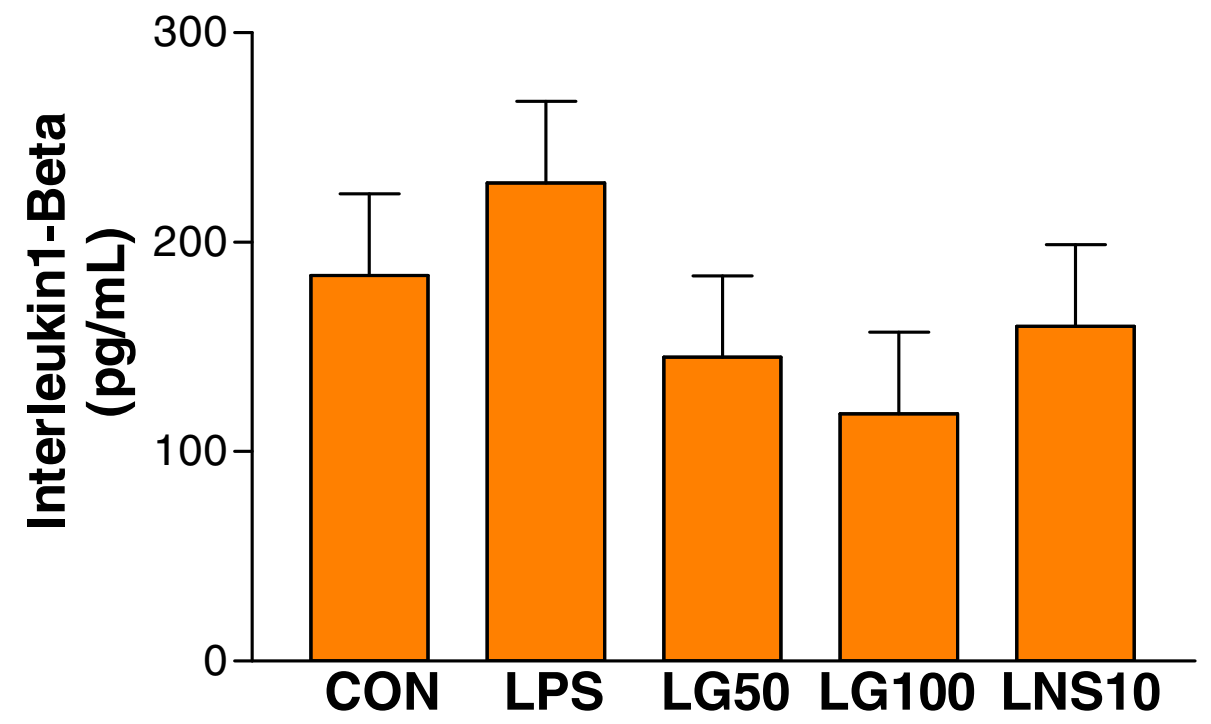

Figure 5. Represents IL-1 $\beta$ level in culture supernatant which was measured via ELISA kit. CON, control without added lipopolysaccharide; LPS, $1 \mu \mathrm{g} / \mathrm{mL} ; \mathrm{LG} 25,25 \mu \mathrm{M}$ genistein; LG50, $50 \mu \mathrm{M}$ genistein; LG100, $100 \mu \mathrm{M}$ genistein; LG200, $200 \mu \mathrm{M}$ genistein; and LNS10, $10 \mu \mathrm{M}$ Viox. All treatment groups were treated with $1 \mu \mathrm{g} / \mathrm{mL}$ LPS. Bars represent mean $\pm \mathrm{SE}, \mathrm{n}=4$ per treatment group. 


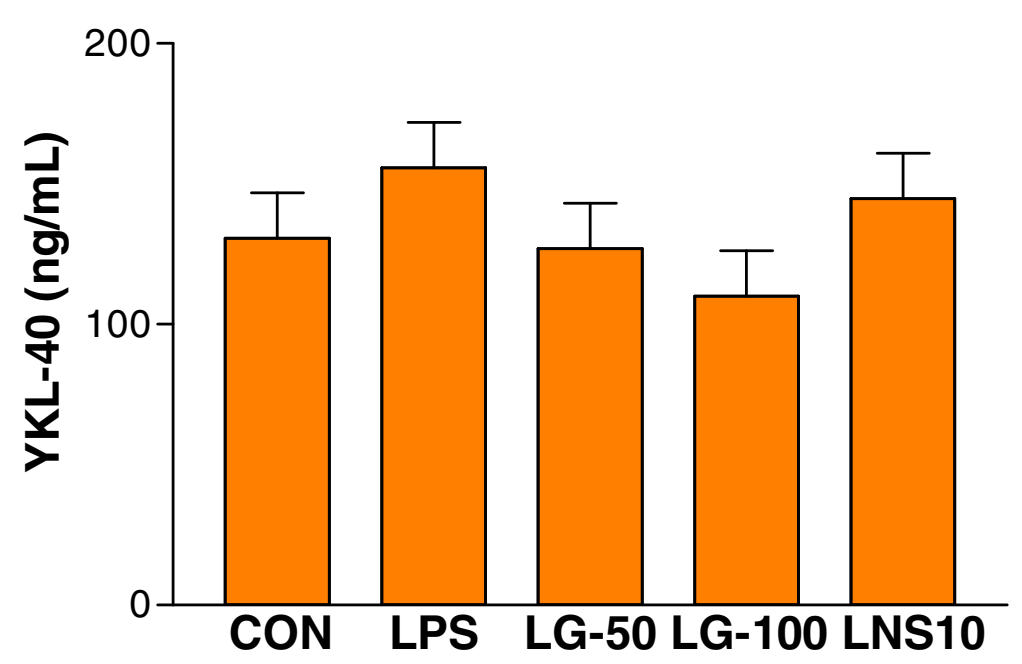

Figure 6. Represents YKL-40 level in culture supernatant which was measured via EIA kit. CON, control without added lipopolysaccharide; LPS, $1 \mu \mathrm{g} / \mathrm{mL}$; LG25, $25 \mu \mathrm{M}$ genistein; LG50, $50 \mu \mathrm{M}$ genistein; LG100, $100 \mu \mathrm{M}$ genistein; LG200, $200 \mu \mathrm{M}$ genistein; and LNS10, $10 \mu \mathrm{M}$ Viox. All treatment groups were treated with $1 \mu \mathrm{g} / \mathrm{mL}$ LPS. Bars represent mean $\pm \mathrm{SE}, \mathrm{n}=4$ per treatment group. 


\section{Reference List}

1. Rosner IA, Goldberg VM, Moskowitz RW. Estrogens and osteoarthritis. Clin.Orthop.Relat Res 1986;77-83.

2. Tsai CL, Liu TK. Up-regulation of estrogen receptors in rabbit osteoarthritic cartilage. Life Sci. 1992;50:1727-35.

3. Shanil juma. The role of estrogen and estrogen receptors in knee osteoarthritis. 2002.

4. Manthey JA. Biological properties of flavonoids pertaining to inflammation. Microcirculation. 2000;7:S29-S34.

5. Maroney AC. Motoneuron apoptosis is blocked by CEP-1347 (KT 7515), a novel inhibitor of the JNK signaling pathway. J Neurosci. 1998;18:104-11.

6. Laughton MJ, Evans PJ, Moroney MA, Hoult JR, Halliwell B. Inhibition of mammalian 5-lipoxygenase and cyclo-oxygenase by flavonoids and phenolic dietary additives. Relationship to antioxidant activity and to iron ion-reducing ability. Biochem.Pharmacol. 1991;42:1673-81.

7. Arjmandi BH, Khalil DA, Lucas EA et al. Soy protein may alleviate osteoarthritis symptoms. Phytomedicine 2004;11:567-75.

8. Tsai CL, Liu TK, Chen TJ. Estrogen and osteoarthritis: a study of synovial estradiol and estradiol receptor binding in human osteoarthritic knees.

Biochem.Biophys.Res Commun. 1992;183:1287-91.

9. Guiducci S, Del Rosso A, Cinelli M et al. Rheumatoid synovial fibroblasts constitutively express the fibrinolytic pattern of invasive tumor-like cells. Clin.Exp.Rheumatol. 2005;23:364-72.

10. Bassleer CT, Franchimont PP, Henrotin YE, Franchimont NM, Geenen VG, Reginster JY. Effects of ipriflavone and its metabolites on human articular chondrocytes cultivated in clusters. Osteoarthritis.Cartilage. 1996;4:1-8.

11. Dawson J, Linsell L, Zondervan K et al. Epidemiology of hip and knee pain and its impact on overall health status in older adults. Rheumatology.(Oxford) 2004;43:497-504.

12. Buckwalter JA, Saltzman C, Brown T. The impact of osteoarthritis: implications 
for research. Clin.Orthop.Relat Res 2004;S6-15.

13. Birchfield PC. Osteoarthritis overview. Geriatr.Nurs. 2001;22:124-30.

14. Hart DJ, Spector TD. Kellgren \& Lawrence grade 1 osteophytes in the knee-doubtful or definite? Osteoarthritis.Cartilage. 2003;11:149-50.

15. Lawrence RC, Helmick CG, Arnett FC et al. Estimates of the prevalence of arthritis and selected musculoskeletal disorders in the United States. Arthritis Rheum. 1998;41:778-99.

16. Felson DT, Zhang Y, Hannan MT et al. The incidence and natural history of knee osteoarthritis in the elderly. The Framingham Osteoarthritis Study. Arthritis Rheum. 1995;38:1500-5.

17. Felson DT. An update on the pathogenesis and epidemiology of osteoarthritis. Radiol.Clin.North Am 2004;42:1-9, v.

18. Felson DT. Osteoarthritis. Rheum.Dis.Clin.North Am 1990;16:499-512.

19. Brown SJ, Pollintine P, Powell DE, Davie MW, Sharp CA. Regional differences in mechanical and material properties of femoral head cancellous bone in health and osteoarthritis. Calcif.Tissue Int. 2002;71:227-34.

20. Fazzalari NL, Kuliwaba JS, Forwood MR. Cancellous bone microdamage in the proximal femur: influence of age and osteoarthritis on damage morphology and regional distribution. Bone 2002;31:697-702.

21. Buckwalter JA. Joint distraction for osteoarthritis. Lancet 1996;347:279-80.

22. Buckwalter JA, Lane NE. Athletics and osteoarthritis. Am J Sports Med. 1997;25:873-81.

23. Buckwalter JA. Activity vs. rest in the treatment of bone, soft tissue and joint injuries. Iowa Orthop.J 1995;15:29-42.

24. Cole AA, Kuettner KE. MMP-8 (neutrophil collagenase) mRNA and aggrecanase cleavage products are present in normal and osteoarthritic human articular cartilage. Acta Orthop Scand.Suppl 1995;266:98-102.

25. Altman R, Asch E, Bloch D et al. Development of criteria for the classification and reporting of osteoarthritis. Classification of osteoarthritis of the knee. Diagnostic and Therapeutic Criteria Committee of the American Rheumatism Association. Arthritis Rheum. 1986;29:1039-49.

26. Altman RD, Block DA, Brandt KD et al. Osteoarthritis: definitions and criteria. Ann.Rheum.Dis. 1990;49:201. 
27. Hochberg MC, Altman RD, Brandt KD et al. Guidelines for the medical management of osteoarthritis. Part II. Osteoarthritis of the knee.American College of Rheumatology. Arthritis Rheum. 1995;38:1541-6.

28. Mitchell NS, Cruess RL. Classification of degenerative arthritis. Can.Med.Assoc J 1977;117:763-5.

29. Buckwalter JA, Rosenberg LC. Electron microscopic studies of cartilage proteoglycans. Electron Microsc.Rev. 1988;1:87-112.

30. Buckwalter JA. Building on our strengths. J Orthop.Res 1990;8:917-20.

31. BendeK TG. A history of the understanding of cartilage. Osteoarthritis.Cartilage. 2005;1-7 (abstr).

32. Buckwalter JA, Mankin HJ, Grodzinsky AJ. Articular cartilage and osteoarthritis. Instr.Course Lect. 2005;54:465-80.

33. Stockwell RA. Chondrocytes. J Clin.Pathol.Suppl (R.Coll.Pathol.) 1978;12:7-13.

34. Aydelotte MB SBKKE. Heterogeneity of articular chondrocytes. Articular cartilage and osteoarthritis 1992;237-49 (abstr).

35. Aydelotte MB MLRD. Chondrocytes from the articular surface and deep zone express different, but stable, phenotypes in alginate gel culture. Trans Orthop Res Soc 1996;21:317 (abstr).

36. Lapadula G, Iannone F. Metabolic activity of chondrocytes in human osteoarthritis as a result of cell-extracellular matrix interactions. Semin.Arthritis Rheum. 2005;34:9-12.

37. Mow VC RM, Woo SLY BJ. Articular cartilage: Biomechanics. In Injury and Repair of the Muscloskeletal Soft Tissue. American Academy of Orthopaedic Surgeons 1988;427-63 (abstr).

38. Athanasiou KA, Rosenwasser MP, Buckwalter JA, Malinin TI, Mow VC. Interspecies comparisons of in situ intrinsic mechanical properties of distal femoral cartilage. J Orthop Res 1991;9:330-40.

39. Goggs R, Carter SD, Schulze-Tanzil G, Shakibaei M, Mobasheri A. Apoptosis and the loss of chondrocyte survival signals contribute to articular cartilage degradation in osteoarthritis. Vet.J 2003;166:140-58.

40. Rosenberg ZS, Shankman S, Steiner GC, Kastenbaum DK, Norman A, Lazansky MG. Rapid destructive osteoarthritis: clinical, radiographic, and pathologic features. Radiology 1992;182:213-6.

41. Ismaiel S, Atkins RM, Pearse MF, Dieppe PA, Elson CJ. Susceptibility of normal 
and arthritic human articular cartilage to degradative stimuli. Br.J Rheumatol. 1992;31:369-73.

42. Kraus VB. Pathogenesis and treatment of osteoarthritis. Med.Clin.North Am 1997;81:85-112.

43. Dequeker J. The relationship between osteoporosis and osteoarthritis. Clin.Rheum.Dis. 1985;11:271-96.

44. Sokoloff L. Osteoarthritis as a remodeling process. J Rheumatol. 1987;14 Spec No:7-10.

45. Mitrovic DR, Riera H. Synovial, articular cartilage and bone changes in rapidly destructive arthropathy (osteoarthritis) of the hip. Rheumatol.Int. 1992;12:17-22.

46. Poole AR, Nelson F, Hollander A, Reiner A, Pidoux I, Ionescu M. Collagen II turnover in joint diseases. Acta Orthop Scand.Suppl 1995;266:88-91.

47. Radin EL, Rose RM. Role of subchondral bone in the initiation and progression of cartilage damage. Clin.Orthop Relat Res 1986;34-40.

48. Clark JM, Huber JD. The structure of the human subchondral plate. J Bone Joint Surg.Br. 1990;72:866-73.

49. Pelletier JP. The influence of tissue cross-talking on OA progression: role of nonsteroidal antiinflammatory drugs. Osteoarthritis Cartilage 1999;7:374-6.

50. Poole AR, Ionescu M, Fitzcharles MA, Billinghurst RC. The assessment of cartilage degradation in vivo: development of an immunoassay for the measurement in body fluids of type II collagen cleaved by collagenases. $\mathbf{J}$ Immunol.Methods 2004;294:145-53.

51. Setton LA, Elliott DM, Mow VC. Altered mechanics of cartilage with osteoarthritis: human osteoarthritis and an experimental model of joint degeneration. Osteoarthritis Cartilage 1999;7:2-14.

52. Felson DT, Nevitt MC. The effects of estrogen on osteoarthritis. Curr.Opin.Rheumatol. 1998;10:269-72.

53. van Saase JL, van Romunde LK, Cats A, Vandenbroucke JP, Valkenburg HA. Epidemiology of osteoarthritis: Zoetermeer survey. Comparison of radiological osteoarthritis in a Dutch population with that in 10 other populations. Ann.Rheum.Dis. 1989;48:271-80.

54. Oliveria SA, Felson DT, Reed JI, Cirillo PA, Walker AM. Incidence of symptomatic hand, hip, and knee osteoarthritis among patients in a health maintenance organization. Arthritis Rheum. 1995;38:1134-41. 
55. Herndon JH. Osteoarthritis in women after menopause. Menopause 2004;11:499501.

56. Rosner IA, Manni A, Malemud CJ, Boja B, Moskowitz RW. Estradiol receptors in articular chondrocytes. Biochem.Biophys.Res Commun. 1982;106:1378-82.

57. Ushiyama T, Ueyama H, Inoue K, Ohkubo I, Hukuda S. Expression of genes for estrogen receptors alpha and beta in human articular chondrocytes. Osteoarthritis Cartilage 1999;7:560-6.

58. Pelletier JP, DiBattista JA, Roughley P, McCollum R, Martel-Pelletier J. Cytokines and inflammation in cartilage degradation. Rheum.Dis.Clin.North Am 1993;19:545-68.

59. Burger H, van Daele PL, Odding E et al. Association of radiographically evident osteoarthritis with higher bone mineral density and increased bone loss with age. The Rotterdam Study. Arthritis Rheum. 1996;39:81-6.

60. Dequeker J, Boonen S, Aerssens J, Westhovens R. Inverse relationship osteoarthritis-osteoporosis: what is the evidence? What are the consequences? Br.J Rheumatol. 1996;35:813-8.

61. Hannan MT, Felson DT, Anderson JJ, Naimark A, Kannel WB. Estrogen use and radiographic osteoarthritis of the knee in women. The Framingham Osteoarthritis Study. Arthritis Rheum. 1990;33:525-32.

62. Samanta A, Jones A, Regan M, Wilson S, Doherty M. Is osteoarthritis in women affected by hormonal changes or smoking? Br.J Rheumatol. 1993;32:366-70.

63. Nevitt MC, Cummings SR, Lane NE et al. Association of estrogen replacement therapy with the risk of osteoarthritis of the hip in elderly white women. Study of Osteoporotic Fractures Research Group. Arch.Intern.Med. 1996;156:2073-80.

64. Spector TD, Hart DJ, Nandra D et al. Low-level increases in serum C-reactive protein are present in early osteoarthritis of the knee and predict progressive disease. Arthritis Rheum. 1997;40:723-7.

65. Vingard E, Alfredsson L, Malchau H. Osteoarthrosis of the hip in women and its relation to physical load at work and in the home. Ann.Rheum.Dis. 1997;56:2938.

66. Zhang Y, McAlindon TE, Hannan MT et al. Estrogen replacement therapy and worsening of radiographic knee osteoarthritis: the Framingham Study. Arthritis Rheum. 1998;41:1867-73.

67. Paech K, Webb P, Kuiper GG et al. Differential ligand activation of estrogen receptors ERalpha and ERbeta at AP1 sites. Science 1997;277:1508-10. 
68. Kuiper GG, Lemmen JG, Carlsson B et al. Interaction of estrogenic chemicals and phytoestrogens with estrogen receptor beta. Endocrinology 1998;139:4252-63.

69. Kuiper GG, Gustafsson JA. The novel estrogen receptor-beta subtype: potential role in the cell- and promoter-specific actions of estrogens and anti-estrogens. FEBS Lett. 1997;410:87-90.

70. Gustafsson JA. Therapeutic potential of selective estrogen receptor modulators. Curr Opin Chem Biol 1998;2:508-11.

71. Nathan C, Sporn M. Cytokines in context. J Cell Biol 1991;113:981-6.

72. Millward-Sadler SJ, Wright MO, Lee H et al. Integrin-regulated secretion of interleukin 4: A novel pathway of mechanotransduction in human articular chondrocytes. J Cell Biol 1999;145:183-9.

73. Billinghurst RC, Dahlberg L, Ionescu M et al. Enhanced cleavage of type II collagen by collagenases in osteoarthritic articular cartilage. J Clin.Invest 1997;99:1534-45.

74. Trippel SB. Growth factor actions on articular cartilage. J Rheumatol.Suppl 1995;43:129-32.

75. Goldring MB, Sandell LJ, Stephenson ML, Krane SM. Immune interferon suppresses levels of procollagen mRNA and type II collagen synthesis in cultured human articular and costal chondrocytes. J Biol Chem 1986;261:9049-55.

76. Dayer JM, Fenner H. The role of cytokines and their inhibitors in arthritis. Baillieres Clin.Rheumatol. 1992;6:485-516.

77. Smith RJ, Chin JE, Sam LM, Justen JM. Biologic effects of an interleukin-1 receptor antagonist protein on interleukin-1-stimulated cartilage erosion and chondrocyte responsiveness. Arthritis Rheum. 1991;34:78-83.

78. Koch AE, Kunkel SL, Chensue SW, Haines GK, Strieter RM. Expression of interleukin-1 and interleukin-1 receptor antagonist by human rheumatoid synovial tissue macrophages. Clin.Immunol.Immunopathol. 1992;65:23-9.

79. Eastgate JA, Symons JA, Wood NC, Grinlinton FM, di Giovine FS, Duff GW. Correlation of plasma interleukin 1 levels with disease activity in rheumatoid arthritis. Lancet 1988;2:706-9.

80. Johansen JS, Olee T, Price PA, Hashimoto S, Ochs RL, Lotz M. Regulation of YKL-40 production by human articular chondrocytes. Arthritis Rheum. 2001;44:826-37.

81. Hakala BE, White C, Recklies AD. Human cartilage gp-39, a major secretory product of articular chondrocytes and synovial cells, is a mammalian member of a 
chitinase protein family. J Biol Chem 1993;268:25803-10.

82. Hu B, Trinh K, Figueira WF, Price PA. Isolation and sequence of a novel human chondrocyte protein related to mammalian members of the chitinase protein family. J Biol Chem 1996;271:19415-20.

83. Volck B, Ostergaard K, Johansen JS, Garbarsch C, Price PA. The distribution of YKL-40 in osteoarthritic and normal human articular cartilage. Scand.J Rheumatol. 1999;28:171-9.

84. Nyirkos $\mathrm{P}$, Golds EE. Human synovial cells secrete a $39 \mathrm{kDa}$ protein similar to a bovine mammary protein expressed during the non-lactating period. Biochem.J 1990;269:265-8.

85. Volck B, Johansen JS, Stoltenberg M et al. Studies on YKL-40 in knee joints of patients with rheumatoid arthritis and osteoarthritis. Involvement of YKL-40 in the joint pathology. Osteoarthritis Cartilage 2001;9:203-14.

86. Towheed T, Maxwell L, Judd M, Catton M, Hochberg M, Wells G. Acetaminophen for osteoarthritis. Cochrane.Database.Syst.Rev. 2006;CD004257.

87. Fries JF, Bruce B. Rates of serious gastrointestinal events from low dose use of acetylsalicylic acid, acetaminophen, and ibuprofen in patients with osteoarthritis and rheumatoid arthritis. J Rheumatol. 2003;30:2226-33.

88. Cryer B, Kimmey MB. Gastrointestinal side effects of nonsteroidal antiinflammatory drugs. Am J Med. 1998;105:20S-30S.

89. Simon LS, Weaver AL, Graham DY et al. Anti-inflammatory and upper gastrointestinal effects of celecoxib in rheumatoid arthritis: a randomized controlled trial. JAMA 1999;282:1921-8.

90. Laine L, Harper S, Simon T et al. A randomized trial comparing the effect of rofecoxib, a cyclooxygenase 2-specific inhibitor, with that of ibuprofen on the gastroduodenal mucosa of patients with osteoarthritis.Rofecoxib Osteoarthritis Endoscopy Study Group. Gastroenterology 1999;117:776-83.

91. Baum C, Kennedy DL, Forbes MB. Utilization of nonsteroidal antiinflammatory drugs. Arthritis Rheum. 1985;28:686-92.

92. Birbara C, Ruoff G, Sheldon E et al. Efficacy and safety of rofecoxib $12.5 \mathrm{mg}$ and celecoxib $200 \mathrm{mg}$ in two similarly designed osteoarthritis studies. Curr Med.Res Opin 2006;22:199-210.

93. Hawkey CJ, Gitton X, Hoexter G, Richard D, Weinstein WM. Gastrointestinal tolerability of lumiracoxib in patients with osteoarthritis and rheumatoid arthritis. Clin.Gastroenterol.Hepatol. 2006;4:57-66. 
94. Hawkey CJ, Fortun PJ. Cyclooxygenase-2 inhibitors. Curr Opin Gastroenterol. 2005;21:660-4.

95. Ehrich EW, Dallob A, De L, I et al. Characterization of rofecoxib as a cyclooxygenase-2 isoform inhibitor and demonstration of analgesia in the dental pain model. Clin.Pharmacol.Ther. 1999;65:336-47.

96. Hawkey CJ, Yeomans ND. The treatment and prophylaxis of nonsteroidal antiinflammatory drug (NSAID)-associated ulcers and erosions. Can.J Gastroenterol. 1999;13:291, 295.

97. Amin AR, Vyas $\mathrm{P}$, Attur $\mathrm{M}$ et al. The mode of action of aspirin-like drugs: effect on inducible nitric oxide synthase. Proc.Natl.Acad.Sci.U.S A 1995;92:7926-30.

98. Patrignani P, Panara MR, Greco A et al. Biochemical and pharmacological characterization of the cyclooxygenase activity of human blood prostaglandin endoperoxide synthases. J Pharmacol.Exp.Ther. 1994;271:1705-12.

99. Dubois RN, Abramson SB, Crofford L et al. Cyclooxygenase in biology and disease. FASEB J 1998;12:1063-73.

100. Crofford LJ. Clinical experience with specific COX-2 inhibitors in arthritis. Curr Pharm.Des 2000;6:1725-36.

101. Anderson JW, Johnstone BM, Cook-Newell ME. Meta-analysis of the effects of soy protein intake on serum lipids. N.Engl.J Med. 1995;333:276-82.

102. Arjmandi BH, Smith BJ. Soy isoflavones' osteoprotective role in postmenopausal women: mechanism of action. J Nutr.Biochem. 2002;13:130-7.

103. Largo R, Alvarez Soria MA, Diez Ortego I et al. Glucosamine inhibits IL-1betainduced NFkappaB activation in human osteoarthritic chondrocytes. Osteoarthritis Cartilage 2003;11:290-8.

104. Smith WL, DeWitt DL, Garavito RM. Cyclooxygenases: structural, cellular, and molecular biology. Annu.Rev Biochem. 2000;69:145-82.

105. Hungin AP, Rubin GP. Management of dyspepsia across the primary-secondary healthcare interface. Dig.Dis. 2001;19:219-24.

106. Brooks P. Use and benefits of nonsteroidal anti-inflammatory drugs. Am J Med. 1998;104:9S-13S.

107. Silverstein FE, Faich G, Goldstein JL et al. Gastrointestinal toxicity with celecoxib vs nonsteroidal anti-inflammatory drugs for osteoarthritis and rheumatoid arthritis: the CLASS study: A randomized controlled trial. Celecoxib Long-term Arthritis Safety Study. JAMA 2000;284:1247-55. 
108. Borden P, Solymar D, Sucharczuk A, Lindman B, Cannon P, Heller RA. Cytokine control of interstitial collagenase and collagenase-3 gene expression in human chondrocytes. J Biol Chem 1996;271:23577-81.

109. Goldring MB. The role of the chondrocyte in osteoarthritis. Arthritis Rheum. 2000;43:1916-26.

110. Clancy RM, Amin AR, Abramson SB. The role of nitric oxide in inflammation and immunity. Arthritis Rheum. 1998;41:1141-51.

111. Badger AM, Cook MN, Swift BA, Newman-Tarr TM, Gowen M, Lark M. Inhibition of interleukin-1-induced proteoglycan degradation and nitric oxide production in bovine articular cartilage/chondrocyte cultures by the natural product, hymenialdisine. J Pharmacol.Exp.Ther. 1999;290:587-93.

112. Blanco FJ, Ochs RL, Schwarz H, Lotz M. Chondrocyte apoptosis induced by nitric oxide. Am J Pathol. 1995; 146:75-85. 
VITA

Shirin Hooshmand

Candidate for the Degree of

Master of Science

Thesis: GENISTEIN REDUCES PRODUCTION OF PROINFLAMMATORY MOLECULES IN HUMAN CHONDROCYTES

Major Field: Nutritional Sciences

Biographical:

Education: Received Bachelor of Science in Nutritional Sciences from Shahid Beheshti University of Medical Sciences, Tehran, Iran, 2004. Completed the requirements for the Master of Science degree with a major in Nutritional Sciences at Oklahoma State University, Stillwater, Oklahoma in May 2006.

Experience: Graduate Research assistance, Department of Nutritional Sciences, Oklahoma State University, Stillwater, OK, 2004 to May 2006. Discussion instructor, Department of Nutritional Sciences, Oklahoma State University, Stillwater, OK, Spring 2006. Teaching Assistant, Department of Nutritional Sciences, Oklahoma State University, Stillwater, OK, Fall 2005 to May 2006. 
Name: Shirin Hooshmand

Institution: Oklahoma State University
Date of Degree: May, 2006

Location: Stillwater, Oklahoma

Title of Study: GENISTEIN REDUCES PRODUCTION OF PROINFLAMMATORY MOLECULES IN HUMAN CHONDROCYTES

Pages in Study: 48

Candidate for the Degree of Master of Science

Major Field: Nutritional Sciences

Previously, we reported that cartilage is an estrogen receptor (ER) positive tissue and that mRNA levels of ERß increase in postmenopausal women with osteoarthritis. Based on our findings and those of other investigators, we hypothesized that local rather than circulating estrogen levels negatively affect chondrocyte metabolism and that selective estrogen receptor modulators (SERM) augment cartilage health. To test the latter part of our hypothesis, we explored the role of genistein, a naturally occurring SERM with high affinity to bind ERß, in inhibiting the lipopolysaccharide (LPS)-stimulated cyclooxygenase (COX)-2 but not COX-1 in human chondrocytes $(\mathrm{HCH})$. Cells (PromoCell, Germany) were treated with three levels of genistein $(0,50$, and $100 \mu \mathrm{M})$. After one hour, the genistein-treated cells were stimulated by one $\mu \mathrm{g} / \mathrm{mL}$ LPS for six hours. Cells were then harvested and the cytosolic fraction was isolated for assessing COX-1 and COX-2 protein levels using Western blot technique. Nitric oxide (NO), interleukin-I Beta (IL-1 $\beta$ ), and YKL-40 productions were also measured in cell culture supernatants. NO, and IL-1 $\beta$ were measured as markers of inflammation and YKL-40 was assessed as a marker of cartilage catabolism. Interestingly, LG50 was more effective in reducing NO production than LG100 (42\% vs. $28 \%$ ) in comparison with LPS-treatred control cells. Genistein had no significant effect on either YKL-40 or IL-1 $\beta$ levels. Our data indicate that the LPS-stimulated increases in COX-2 protein level and $\mathrm{NO}$ in supernatant are reduced by pretreatment of genistein, whereas COX-1 protein level is not affected by genistein.

ADVISER'S APPROVAL: Dr. Bahram H. Arjmandi 